\title{
Modelling of Nature-Based Solutions (NBS) for Urban Water Management-Investment and Outscaling Implications at Basin and Regional Levels
}

\author{
Berhanu Fanta Alemaw, Thebeyame Ron Chaoka, Nata Tadesse Tafesse \\ Department of Geology, University of Botswana, Gaborone, Botswana \\ Email: alemaw@ub.ac.bw, bfalemaw@gmail.com, chaokatr@mopipi.ub.bw,Nata.Tafesse@ub.ac.bw
}

How to cite this paper: Alemaw, B.F., Chaoka, T.R. and Tafesse, N.T. (2020) Modelling of Nature-Based Solutions (NBS) for Urban Water Management-Investment and Outscaling Implications at Basin and Regional Levels. Journal of Water Resource and Protection, 12, 853-883.

https://doi.org/10.4236/jwarp.2020.1210050

Received: September 2, 2020

Accepted: October 26, 2020

Published: October 29, 2020

Copyright $\odot 2020$ by author(s) and Scientific Research Publishing Inc. This work is licensed under the Creative Commons Attribution International License (CC BY 4.0).

http://creativecommons.org/licenses/by/4.0/

\begin{abstract}
This manuscript is an attempt to demonstrate effectiveness of nature-based solutions (NBS) and measures to reduce risk of flooding and environmental impact in urban settings. The nature-based solutions (NBS) were assessed as scenarios from experience of urban storm drainage and sewerage systems based on practices that improve urban water management through modelling using urban stormwater management model (SWMM). The model has been applied in a typical urban environment in the second city in Botswana, the City of Francistown, which has a population of more than one hundred thousand. By considering the 2-yr and 10-year storm events in a calibrated SWMM, NBS scenarios from a mix of low impact and drainage measures were considered. The considered NBS scenarios were used to determine their effectiveness in terms of reducing and controlling peak runoff, flood volumes, infiltration and evapotranspiration in the study area, which are vital in assessing the opportunity and challenge for sustainable management of water resources and associated tradeoff of investments in the urban contexts. The study demonstrates the usefulness of implementing effective measures for achieving NBS in urban context and possibility of outscaling at basin and regional levels.
\end{abstract}

\section{Keywords}

Modelling of Urban Drainage, SWMM, Sustainable Urban Water Management, Nature-Based Solutions (NBS), Africa

\section{Introduction}

Improving urban water management, both its quantity and quality, require a 
number of approaches and tools including the most recent tools such as the nature based solutions (NBS) as elaborated in [1] [2].

The four pillars of critical water management include improving water availability, water access, enhancing water quality, and risk mitigation. Furthermore, implementation of NBS for multiple water-related benefits and co-benefits requires case study sites in different regions and basins to draw best practices and lessons to meet water demands for domestic, industrial, mining and other extractive ventures.

Different regions (and sub-regions) can face similar or different water-related challenges at varying intensities, which stem from a combination of physical hydrological conditions as well as the state of overall water resource management, including governance, capacity, economics and finance. Although this may result in a different mix and level of implementation of NBS, certain similarities can emerge and thus lessons learned in one country or region can help inform the implementation of NBS in another as stipulated in [1] [2].

In addition, the accelerated urbanization has changed urban underlying surface, and the impervious proportion areas have increased, resulting in lots of serious urban water problems [3]. Besides, urbanization, global climate change has been the cause for increase of the frequency of extreme rainstorms [4]. Nature based solutions are required to achieve sustainability in the sustainable water management and effective risk mitigation for urban settlements.

In the late 1990s, low impact development (LID) as a new conception was proposed in order to solve stormwater problem [5]. LIDs could control runoff from the source through infiltration, filtration, evapotranspiration and other natural hydrological processes, aiming to the reduction of runoff quantity and pollution, and the protection of the receiving water, which is different from traditional stormwater management [6]. The concept of LID has been developed to include water management as part of urban planning and development concepts including, Sponge city [6] [7], Sustainable Urban Water Management (SUWM) [8]; Water Sensitivity Urban Design (WSUD) [9]; and Sustainable Urban Drainage System (SUDS) [10] [11]. The concept and review of Sustainable Urban Drainage Systems Considering the Climate Change and Urbanization Impacts is elaborated in [12].

The concept of Sponge city originates from the traditional urban water service model, which evolved multiple phases that caters for urban water management challenges [13] [14]. A sponge city is a city structured and designed to absorb and capture rain water and utilize it to reduce floods. Rain water harvested can be repurposed for. It is a form of a sustainable drainage system on an urban scale. Besides additional benefits of irrigation, homeuse and improving overall water quality, the concept can be used for reducing urban heat [15].

With growing provision of complete water service infrastructure, sewerage and wastewater treatment works, the capacity of these infrastructures were challenged by increasing urban runoff. The urban drainage system is the source of 
huge flows and pollution joining the sewerage systems and wastewater treatment works (WTWs). Urban waterlogging not only affects social and economic development besides causing great inconvenience to residents and even injuries [16].

With the growth of urban areas and more extended paved urban areas, more Sewage or Wastewater Treatment Works (WTWs) are introduced. Combined with water pipes, sewers and WTWs in urban areas the focus has grown to more flood protection and drainage control. All these urban development and urban runoff control measures contribute and necessitate Sustainable Urban Water Management (SUWM) practices [10] [11].

Systemic urban landscape design should carefully consider dynamism, heterogeneity and its role in maintaining desirable functions such as biodiversity, storm water retention, microclimate mitigation, and carbon sequestration, as well as natural disturbances, extreme climate events, shifting economic investment or disinvestment in the urban environment [17].

In the North America formed another similar technique, named Low Impact Development (LID) in the end of 1990s, which originated as a design philosophy to minimize the impact on environment by the approaches of design and developing, and management process. During the practice of realizing LID, urban designers and developers must show their respect to water, surface soil, terrain, and vegetation, that is, to respect nature, which marks the core value of LID [6].

Active Beautiful Clean $(\mathrm{ABC})$ Waters Program which has been able to contribute to widespread LID technique was introduced in April 2006 by Singapore's water agency to carry out stormwater management in a more sustainable manner. This $A B C$ Program is primarily used to managing urban stormwater and controlling flood which is also becoming popular in countries of the northern hemisphere [18].

The urban storm runoff treatment concept was introduced which synonymously called as Sustainable Urban Drainage System (SUDS) ([10] [11] [19]. The concept focuses on making use of and strengthening natural process to simulate hydrologic development in early time, which subverts principals of rapid transit [20]. Besides, runoff quantity, SUDS is also applied as an intervention to improve urban flood and water contamination and urban beautification, and to provide a more livable environment for both human and wildlife [21] [22].

The high degree of urbanization put pressures on ecosystems of both local and regional lifesupport where ecological principles could guarantee sustainability where a practical tool for eco-sustainable planning and management is required [17] [23]. The idea of Sponge city plays a pivotal part in the construction of ecological landscape, provides a livable and sustainable environment, also becomes the basis of evaluating the ecological environment of urban residents [24].

In Botswana where the study case site is considered and the southern Africa in general, there is a growing focus on sustainable development planning in rural 
and urban areas, improved urban development standards and improved drainage manuals to respond to infrastructural challenges and changed climate conditions which resulted in increase of frequency and intensity of heavy storms [25]-[30]. The main objectives of this study were therefore:

To model and assess various plausible NBS scenarios in urban setting.

To analyze the implications for implementing NBS at urban scale.

To discuss the challenges and limitations of NBS implementation.

To elucidate the enabler conditions for uptake of NBS across different scales.

Furthermore, through the studied case study site and different cases in Africa, recommendations for improving implementation of NBS at a scale of urban settings, basin and regional levels is also provided.

\section{Data and Methods}

\subsection{Study Area, Sub-Catchments and Design Storms}

The study area is focused on the watershed area encompassing the drainage and sewerage layout of the City of Francistown in north-eastern Botswana. The area drains the Confluence Rivers of Ntshe and Tati Rivers before joining Shashe River towards the Limpopo Drainage Basin. Data from [31] was used to define the drainage areas and drainage characteristics, such as slopes, lengths, besides the network map of the sewerage system. The considered subareas and the location are presented in Table 1 and Figure 1.

Storm Intensity-Duration-Frequency (IDF) Curves were used to determine the design storms which are the basis of the design of the drainage system. In addition to the average storm intensity within certain duration, the time-distributed form, i.e. the rainfall pattern, is also an important factor. For rainfall patterns in many generalized studies, the Chicago model is widely used as suggested by [32]. This model, in the rainfall intensity mode represents the maximum average intensity rule of the same frequency, introduces the average shape and intensity peak position, and can obtain the average rainfall intensity, time-interval rainfall intensity and instantaneous rainfall intensity. The model described by the

Table 1. Highlights of the drainage subareas considered in the study area.

\begin{tabular}{|c|c|c|}
\hline Subcacthment & Locality & Drainage description \\
\hline Subarea 1 & Aerodrome & Area draining south-easterly at the outlet neat Tati West. \\
\hline Subarea 2 & Central & Area conferencing Tati river, draining in southwesterly direction. \\
\hline Subarea 3 & Gerald & South-western basin flowing in the easterly direction towards Mambo. \\
\hline Subarea 4 & Phase 4 & South of Somerset East and Satellite draining to the outfall of Mambo. \\
\hline Subarea 5 & Satellite & $\begin{array}{l}\text { South eastern portion and area draining Satellite, Somerset East } \\
\text { Extension, Donga and Phase V-I. }\end{array}$ \\
\hline Subarea 6 & Madzibalori & $\begin{array}{l}\text { Area including Madzibalori and northern areas of Government Camp, } \\
\text { Phase V-3, Monarch and Dumela. }\end{array}$ \\
\hline System area & Study area & $\begin{array}{l}\text { Entire catchment area draining to outfall at Mambo WWTP to Tati } \\
\text { River }\end{array}$ \\
\hline
\end{tabular}




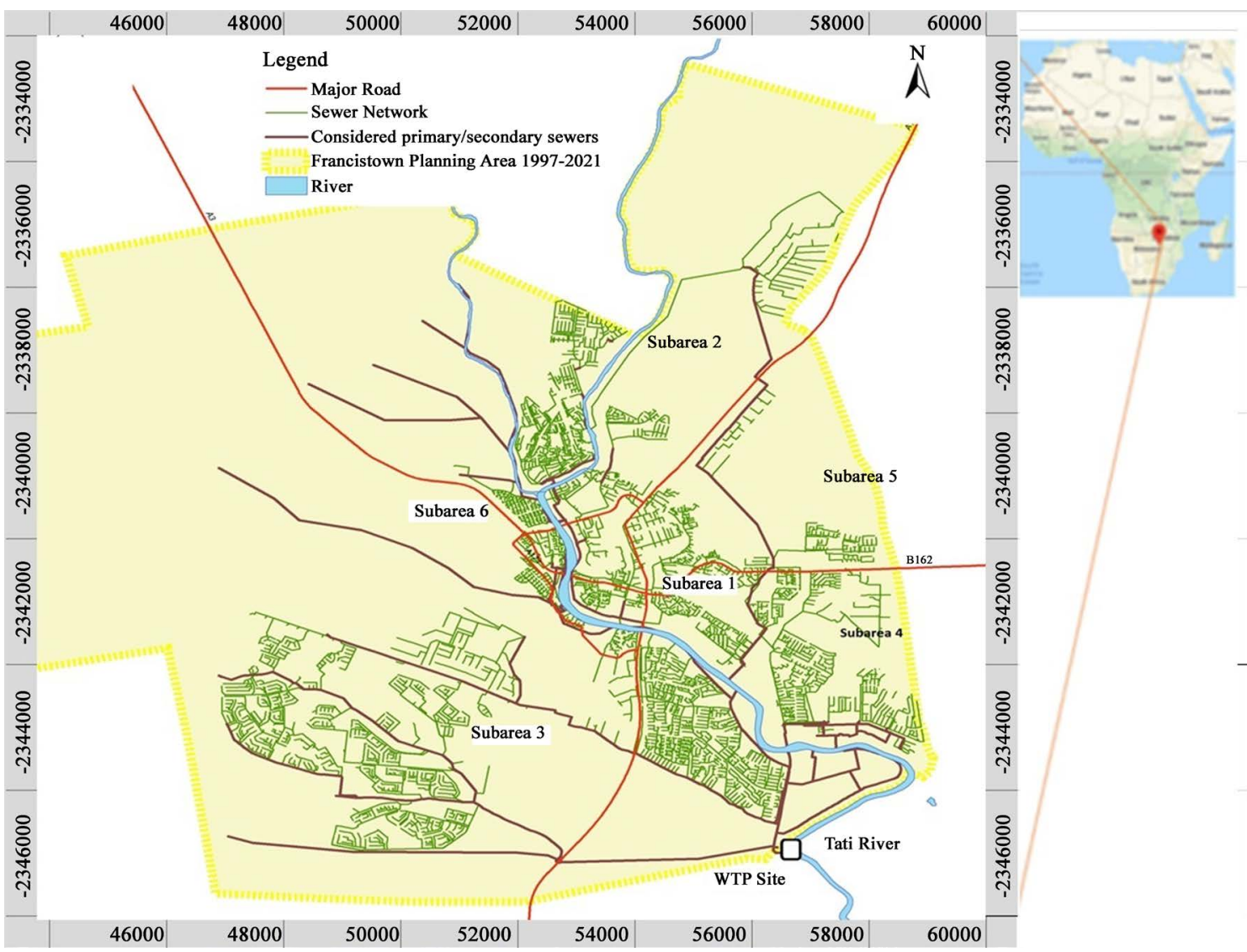

Figure 1. Location of the study sewerage network area in the City of Francistown, Botswana.

instantaneous intensity summarizes the special rainfall patterns, forming a rainfall pattern that more fully reflects the characteristics of storms.

In the absence of long-recorded data of short storm events/storm depths of short durations, it is always difficult to develop an IDF curve for a given region. However, based on a parsimonious robust frequency modelling approach it was possible to model 24-hour maximum rainfall frequency and construct the IDF curves from existing best practices. For this purpose, the IDF curves were constructed based on [33] and rainfall incremental depths for hourly durations were based on the Botswana Roads Design Manual, Volume 3, Hydrology and Road Drainage [28].

\subsection{Flooding and Flows}

In the main study area of an urban drainage challenge in City of Francistown, there have been frequent incidences of flooding in the City as summarized in Figure 2. The 2014 flooding event was the most widespread and intense in the recent past years.

Furthermore, effect of wet weather flow increases in the existing sewerage system and the existing wastewater treatment plant cannot be undermined. These flow increases, will require upgrades in capacity of the urban drainage and sewerage system, with pronounced impact on investments to be made. 

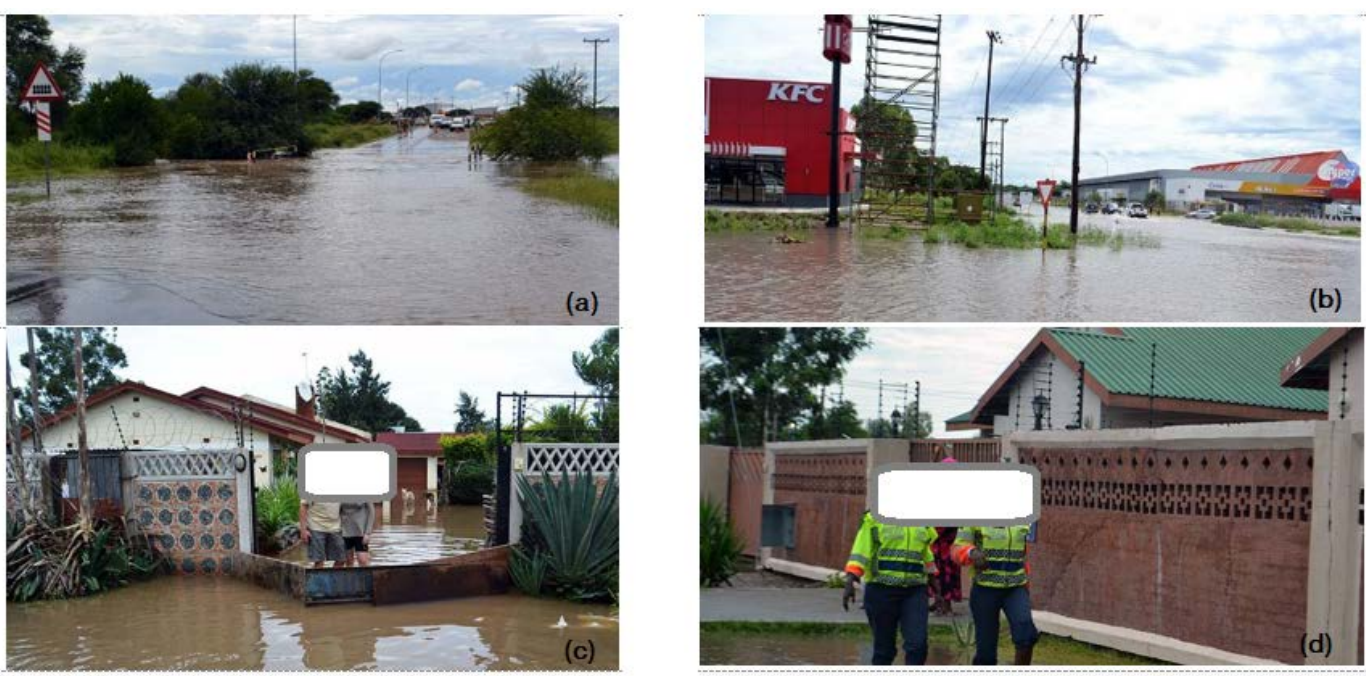

Figure 2. Existing flooding problems in the study area observed in 2014 flooding period (a) Domboshaba road; (b) Road passing Donga; (c) Villa in Tati area and (d) Residential house yard [34].

Unless, sustainable management of excess runoff and treated wastewater are utilized to meet co-benefits, cost-effectiveness of public investments in water supply and sanitation infrastructure will remain questionable and practically unjustifiable.

\subsection{Review of the Existing NBS Tools}

Using prior concepts prior to the advent of NBS, similar approaches are elaborated by different authors. Notable studies were undertaken since 1970s that aimed at developing an urban system which is a combination of several components of urban runoff management and water treatment, synonymously known as Integrated Urban Drainage System (IUDS) [35]. The concept focusses mainly in the integration of sewer, wastewater treatment plant, water receiving systems, and sustainable stormwater management, with economic factors taken into consideration [36].

The concept of Water Sensitivity Urban Design (WSUD) is also applied for planning and design, which first popularized in Australia in the mid of 1990s. The WSUD primarily targets at minimize the adverse effects of urban development on surrounding hydrological environment [37].

The best solution to the rainwater problem in cities should be drainage which involves efficiently collecting and discharging stormwater to receiving waters. This tendency which was popular up to the 1990s has transformed to developing water sensitive city infrastructure and ecosystem services as illustrated in Figure 3.

Review of the existing NBS tools for sustainable water management in urban contexts are elaborated in [2]. Prudent urban water management and promotion of practices of best NBS, included five categories as noted in [2], namely: 1) stormwater management, 2) flood protection and risk management, 3) implementation of blue-green infrastructures, 4) urban water in the field of food, water and energy ecosystem and 5) urban water pollution control and constructed wetlands. 
Increase of environmental knowledge and socio-political awareness of society

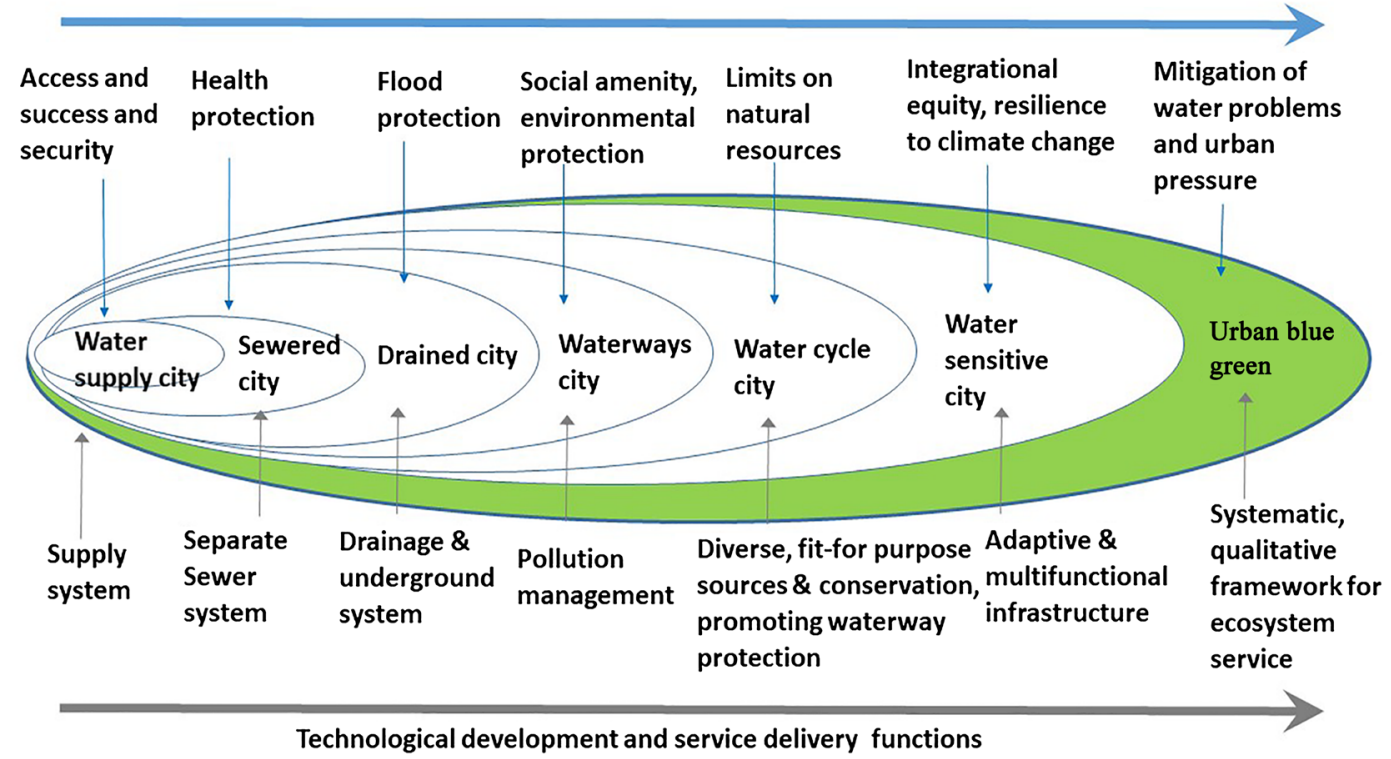

Figure 3. Historical development of water supply and management (modified from [2] [38] [39]).

\subsection{Modeling and NBS Scenarios}

\subsubsection{Modelling Approach}

The modelling approach allows for considering development pattern in urban or watershed level based on source control and decentralized processes for assessing and managing generated runoff at selected outlets.

The modelling facility within EPA's Storm Water Management Model (SWMM) has provisions that allow the conceptualization of LIDs attributable to each target subareas. LID practices are modeled based on the conceptualization of the vertical layers between which SWMM tracks of how much water moves and is stored (Figure 4). Common LIDs are summarized in Figure 5.

Sustainable Urban Drainage Systems (SUDS) technologies consider environmental, social and economic pillars in the design process. SUDS should integrate stakeholders in the decision making and ultimately, could achieve multiple benefits along with flood and inundation mitigation. There are several SUDS technologies available. Within the scope of this study, four of the most popular SUDS technologies were considered:

1) Rainwater harvesting - which can be a supplement for water supply sources; reduce extra direct discharge to the drainage system and prevent urban flooding [40] [41] [42].

2) Green roofs-have numerous benefits [43], including: Reduction of runoff peaks and volumes, resulting in lower urban flood risks [44] [45] [46]; the insulation of heat transfer, resulting in lower cost for air conditioning, and reduction of the heat island effect [42] [47] [48]; reduction in air pollution [49]; provision of wildlife habitat for birds and general enhancement of environment for the area e.g. [42] [50] [51] [52].

3) Urban green space provides improved resiliency in runoff management and 


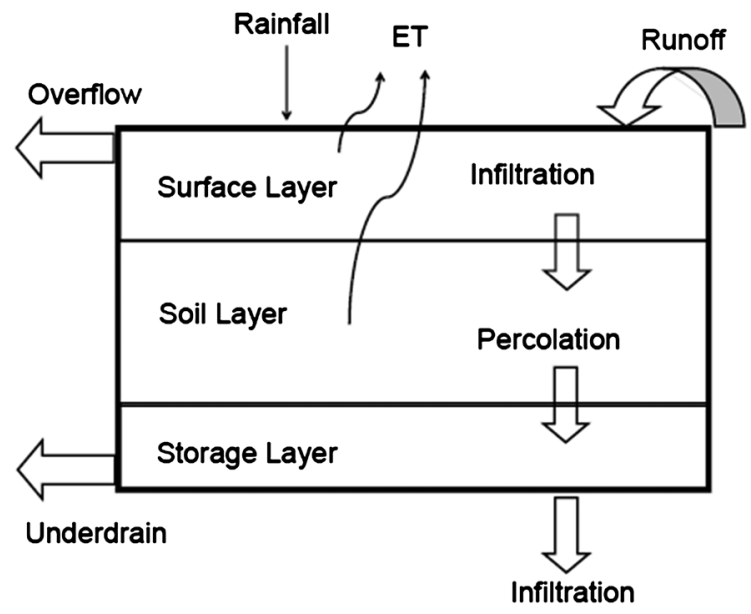

Figure 4. Vertical layer structure of the general arrangement of bioretention in SWMM [61].

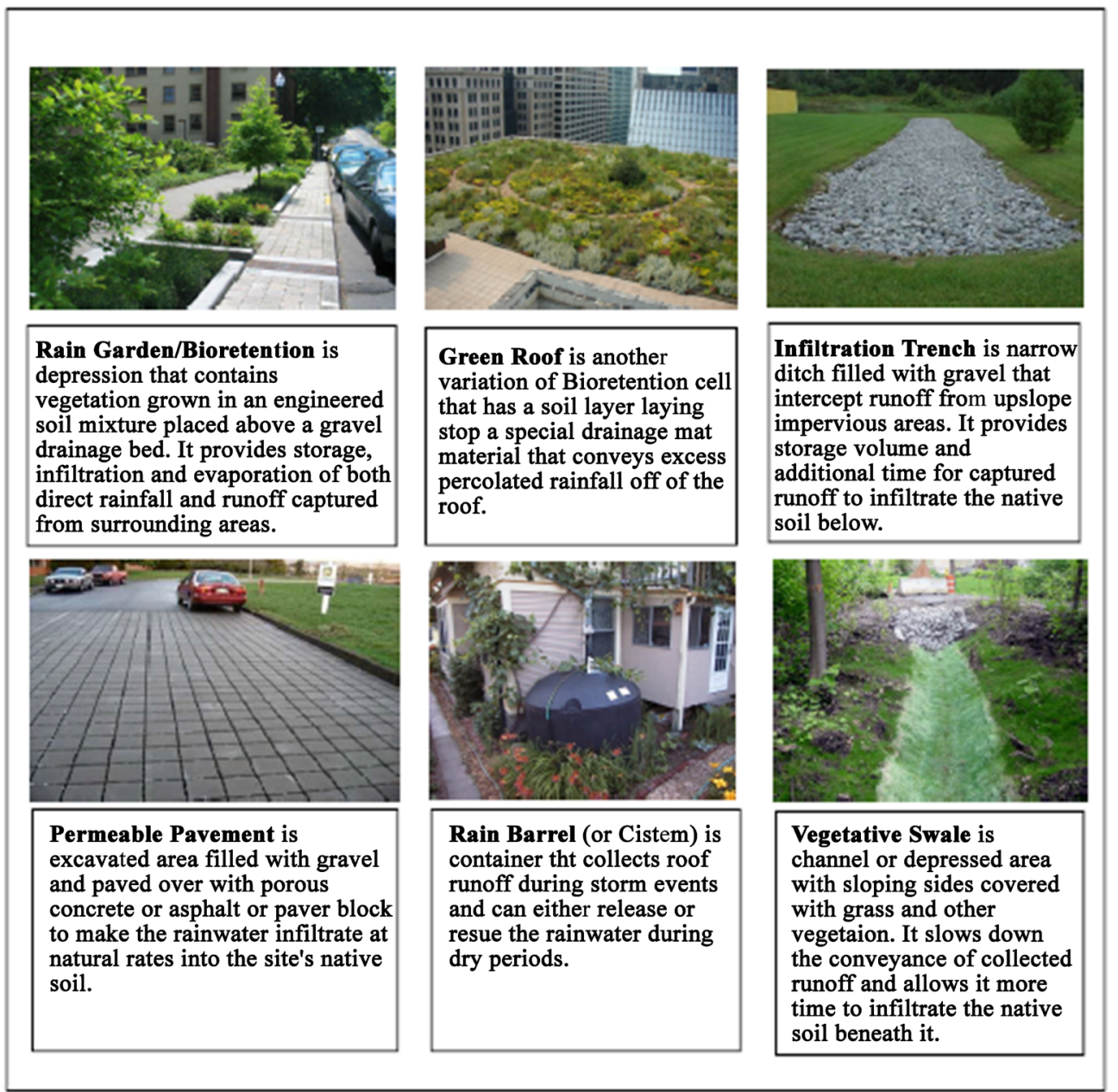

Figure 5. Description of typical LID measures in urban storm water management systems [61].

multiple other ecosystem services [53] [54] [55] [56].

4) Pervious pavement-a technology that both enhances infiltration and improves surface runoff quality [57] [58] [59]. There is some concern about clog- 
ging of pervious pavement, with observed clogging rates being highly variable, but [60] have reported on new generation maintenance methods to regenerate permeability.

A combination of layers used to simulate any LID or a combination of LIDs such as pavement layer, bioretention, vegetative swale, infiltration basins, green roof, and the flow pathways between the layers to allow the surface layer to receive direct rainfall or runoff from adjacent land areas, stores excess inflow in depression storage, and generates surface outflow that either enters the drainage system or flows into adjacent land areas. Vertical layer structure of the general arrangement of bioretention in SWMM is shown in Figure 5.

The pavement layer is the layer of porous materials with permeable system. The soil layer in SWMM is the defined as natural soil mixture or engineered soil mixture used in LIDs to support vegetative growth or provide bedding and filtration. The storage layer consists of crushed rocks or gravels for water storage. The drain system allows water effluent from the storage layer into a common outlet channel or pipe. The drainage mat layer used in green roof is a plate or mat between the soil and the roof to convey water off of the roof.

\subsubsection{Consideration of NBS for the Study Area}

NBS through LID practices that provide stronger control and reduction of runoff volume are biofiltration, rain garden, green and vegetative swales. These measures have some advantage of reducing runoff pollution, landscape enhancement and some economic benefits in terms of tourism and recreation. Equivalently, permeable pavements and infiltration trenches also have some similar advantage with some degree of challenges of economy and landscape due to non-vegetative character of change of surface of the landscape.

The risks associated with flooding faced in the study area urban floods and waterlogging which are currently the most prominent problems which affect not only urban lifestyle but also flooding of the sewerage system at major outfalls and junctions. In most parts of the study area, rainwater pipes in many residential areas directly discharge roof rainwater to the roads, and serious missing of vegetation layer has occurred in landscape flower beds, and unrepaired pavement exits in almost each residential areas. Using the conventional methods, a lot of time and money need to be invested in rebuilding or renovating these facilities.

The urban development standards [29] and the revised hydrology and road drainage design manual [28] calls for better management of urban runoff and harvesting excess runoff and by connecting roof downspouts to urban drainage systems, replanting vegetation layers and paving new roads, etc. With the introduction of LID concept, according to the characteristics of different LIDs, it will be more effective to apply them or the introduction in urban areas, such as adding Rain Barrels connected with roof downspouts to directly collect rainwater from the roof for household water utilization, landscape flower beds into Rain Garden, and transforming damaged pavements into Permeable Pavements, as 
illustrated in Figure 5.

Therefore, based on the characteristics of the various LIDs and the major problems faced by the study area, taking the total runoff and runoff peak control as objectives and meanwhile considering economy and landscape, in this study, vegetative swales, Infiltration trench and permeable pavements or open pavement systems are applied as basic LIDs.

\subsubsection{Nature-Based Solution (NBS) Scenarios}

NBS associated with many engineering practices of LIDs have been designed and their respective effectiveness has also been determined. However, for a mixed LULC (Land Use/Land Cover) area with multiple LIDs (LID practices), the effectiveness on the whole area is still not comprehensive because of mentioned limitations and variety of LIDs. In order to avoid the rainwater management measures being one fold, designing a combined LIDs solution can not only effectively achieve control objectives, but also save costs. In this manuscript, according to the input and output paths and ratios of treated impervious surface and the characteristics of LIDs (vegetative swales, Infiltration trench and permeable pavements) along with development control and drainage (DSD) measures that improve imperviousness in the longterm, four scenarios with different combinations and layouts of LIDs were established to compare their respective effectiveness on controlling runoff volume and peak. Moreover their effectiveness in controlling infiltration and evaporation were also studied.

It is assumed that the various LID and DSD measures constitute the majority of NBS scenarios required to achieve aquatic, environmental and climate resilience in an urban environment where well managed facilities for collection and disposal of urban runoff and sewage flows.

Combined LID measures include a combination of providing vegetative swales, Infiltration trench and permeable pavements or open pavement systems, each covering a third of 1 percent of the catchment area/drainage zone. The LID composite measures are LID 1 (a third of the area provided with vegetative swales); LID 2 ( $0.67 \%$ of the area provided equally with vegetative swales and Infiltration trench); and the remaining LID 3 ( $1.0 \%$ of the area provided equally with vegetative swales, Infiltration trench and permeable pavements or open pavement systems).

Development control and drainage measures (DCD measures) that is a combination of measures related to leveling of residential/property yards to at least $2 \%$, and improving drainage situation in the urban areas that reduce imperviousness by 10, 15 and 20 percent i.e. DCD 10, DCD 15 and DCD 20.

The DCD measures were included apart from the basic LID practices to cater for development control [29] and revised road drainage manual [28] drainage Lot Grading and Drainage requirement to a minimum lot grading around houses and buildings of up to $2 \%$ and the minimum grades for side lot swales and rear lot swales be $2 \%$. Also the hydrology and road drainage manual recommends that all grading design shall be completed in accordance with the governing guide- 
lines and an overland flow route must be established to safely convey runoff from the regulatory storm (in excess of the design capacity of the minor system) within the road right-of-way or easements to the nearest major open channel.

The four scenarios considered therefore were the following:

- NBS Scenario 1 Combined LID composite measures only.

- NBS Scenario 2 Combined LID composite measures with DCD 10.

- NBS Scenario 3 Combined LID composite measures with DCD 15.

- NBS Scenario 4 Combined LID composite measures with DCD 20.

NBS Scenario 1 assumes that the LID area constitutes equal proportion of the three LID measures each covering a third of 1 percent of the catchment area constituting vegetative swales, Infiltration trench and permeable pavements, from which the runoff finally runs into the urban drainage system with no additional impervious area improvement measures taking place in the entire catchment. On other hand, NBS Scenario 2, NBS Scenario 3 and NBS Scenario 4 assume that apart from the LID measures of NBS Scenario 1, slow but sustained measures, stated as development control and drainage measures (DCD measures) will be introduced in the entire urban catchment to improve the imperviousness and drainage collection system in the study catchments to achieve imperviousness reduction by $10 \%, 15 \%$ and $20 \%$, labelled as DCD 10, DCD 15 and DCD 20, respectively. These four NBS Scenarios were built into the SWMM model simulation.

\section{Results and Discussions}

\subsection{Results}

Rainfall characteristics and system response for a 2-year and a 10-year return period rainfall with existing drainage network is shown in Figure 6. Whereas Figure 7 shows runoff hydrograph within existing drainage network for the four NBS Scenarios based on mix of LID and DCD measures.

Table 2 and Table 3 show the summary of the effect of 2 -year storms for the various NBS Scenarios on runoff volume and runoff peak, and Table 4 and Table 5 show effect on evaporation and infiltration in the various subareas of the study area, respectively.

The LID composite measures are LID 1 ( $0.3 \%$ of the area provided with vegetative swales); LID 2 ( $0.67 \%$ of the area provided equally with vegetative swales and Infiltration trench); and the remaining LID 3 (1.0\% of the area provided equally with vegetative swales, Infiltration trench and permeable pavements or open pavement systems).

Runoff within existing drainage network for the four NBS scenarios based on mix of LID and DCD measures is illustrated in Figure 7 with system outflow of the existing drainage network. The four NBS Scenarios shown are: NBS Scenario 1-Combined LID composite measures only; NBS Scenario 2-Combined LID composite measures with DCD 10; NBS Scenario 3-Combined LID composite measures with DCD 15; and NBS Scenario 4 Combined LID composite measures 

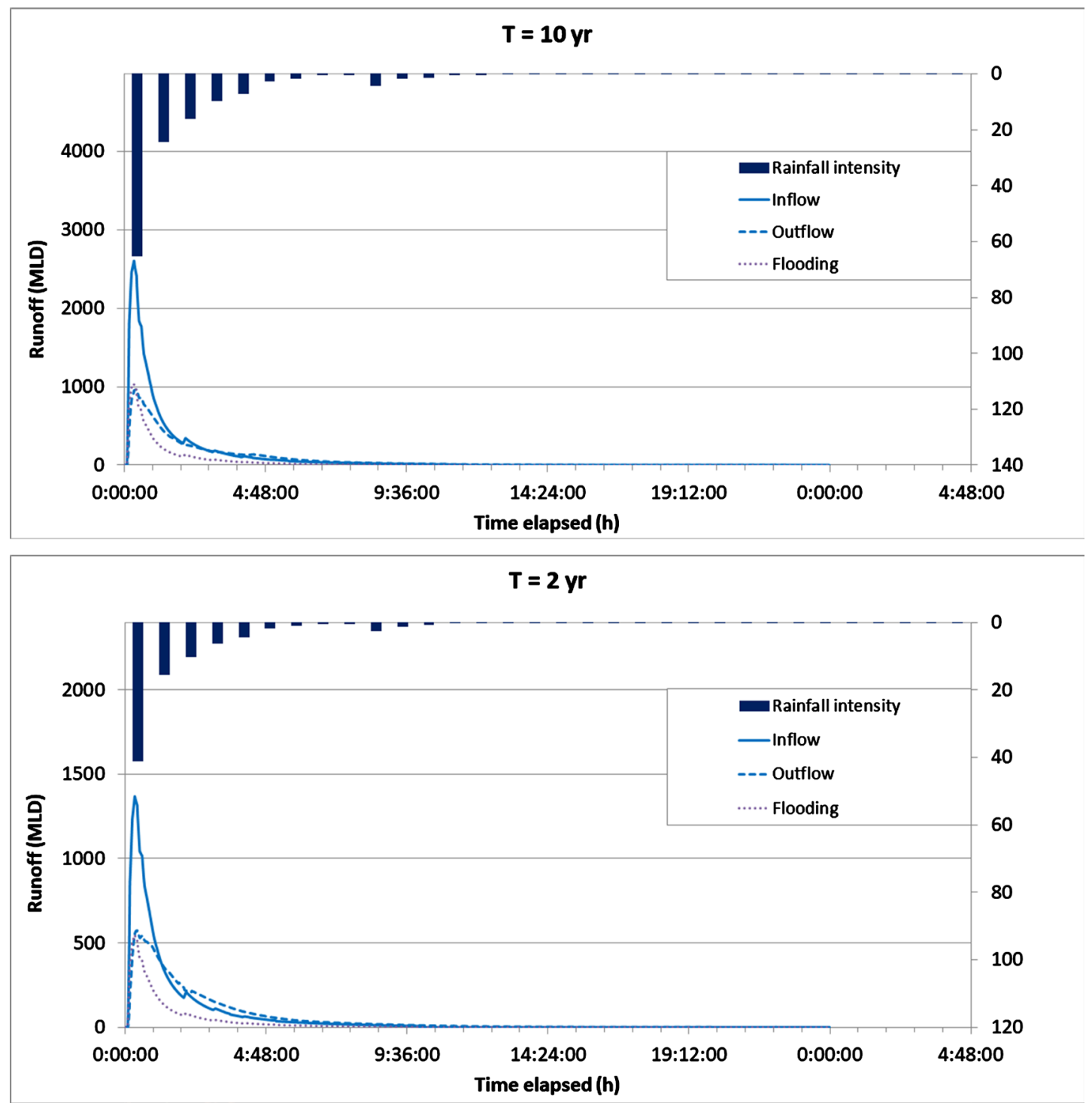

Figure 6. Rainfall characteristics and system response for (a) 2-year and (b) 10-year return period rainfall with existing drainage network.

Table 2. Effect on runoff volume due to 2-year storms for the various NBS Scenarios.

\begin{tabular}{ccccccc}
\hline \multirow{2}{*}{ Catchment } & \multirow{2}{*}{$\begin{array}{c}\text { Rainfall } \\
(\mathrm{mm})\end{array}$} & $\begin{array}{c}\text { Runoff Volume } \\
\left(10^{6} \mathrm{~L}\right)\end{array}$ & NBS Scenario 1 & NBS Scenario 2 & NBS Scenario 3 & NBS Scenario 4 \\
\cline { 4 - 7 } & 10.69 & 10.67 & $-6.4 \%$ & $-47.9 \%$ & $-31.6 \%$ & $-15.6 \%$ \\
\hline Subarea 1 & 10.69 & 9.21 & $-6.5 \%$ & $-47.8 \%$ & $-31.5 \%$ & $-15.5 \%$ \\
Subarea 2 & 10.92 & $-6.1 \%$ & $-52.2 \%$ & $-36.3 \%$ & $-20.5 \%$ \\
Subarea 3 & 10.69 & 13.92 & $-6.1 \%$ & $-49.5 \%$ & $-33.0 \%$ & $-16.4 \%$ \\
Subarea 4 & 10.69 & 18.57 & $-6.2 \%$ & $-49.9 \%$ & $-33.2 \%$ & $-16.6 \%$ \\
Subarea 5 & 10.69 & 6.09 & $-9.4 \%$ & $-49.7 \%$ & $-33.0 \%$ & $-16.5 \%$ \\
Subarea 6 & 10.69 & 4.64 & $-5.3 \%$ & $-46.0 \%$ & $-30.6 \%$ & $-15.3 \%$ \\
System area & 10.69 & 54.87 &
\end{tabular}




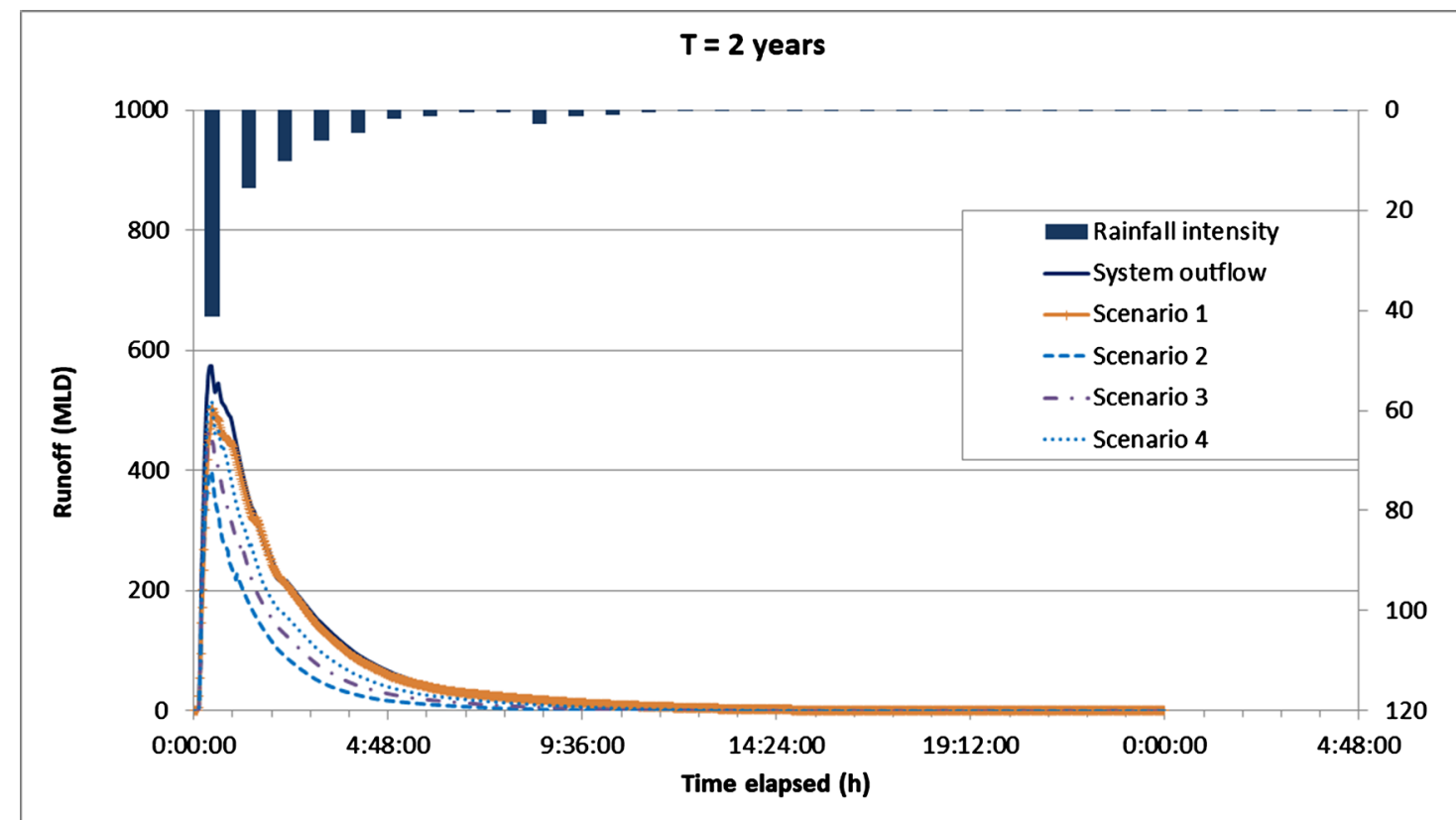

Figure 7. Runoff hydrograph of 2-yr storm within existing drainage network for the four NBS Scenarios based on mix of LID and DCD measures.

Table 3. Effect on peak runoff due to 2-year storms for the various NBS Scenarios.

\begin{tabular}{|c|c|c|c|c|c|c|}
\hline \multirow{2}{*}{ Catchment } & \multirow{2}{*}{$\begin{array}{c}\text { Rainfall } \\
(\mathrm{mm})\end{array}$} & \multirow{2}{*}{$\begin{array}{l}\text { Peak runoff } \\
\quad(\mathrm{CMS})\end{array}$} & \multicolumn{4}{|c|}{ Change in peak runoff } \\
\hline & & & NBS Scenario 1 & NBS Scenario 2 & NBS Scenario 3 & NBS Scenario 4 \\
\hline Subarea 1 & 10.69 & 0.82 & $-6.3 \%$ & $-47.7 \%$ & $-31.4 \%$ & $-15.5 \%$ \\
\hline Subarea 2 & 10.69 & 0.68 & $-6.5 \%$ & $-47.7 \%$ & $-31.3 \%$ & $-15.5 \%$ \\
\hline Subarea 3 & 10.69 & 5.76 & $-6.1 \%$ & $-52.1 \%$ & $-36.2 \%$ & $-20.5 \%$ \\
\hline Subarea 4 & 10.69 & 4.59 & $-6.1 \%$ & $-49.4 \%$ & $-32.8 \%$ & $-16.4 \%$ \\
\hline Subarea 5 & 10.69 & 2.78 & $-6.1 \%$ & $-49.7 \%$ & $-33.1 \%$ & $-16.5 \%$ \\
\hline Subarea 6 & 10.69 & 1.58 & $-9.3 \%$ & $-49.6 \%$ & $-33.0 \%$ & $-16.5 \%$ \\
\hline System area & 10.69 & 6.65 & $-4.2 \%$ & $-41.9 \%$ & $-27.8 \%$ & $-13.8 \%$ \\
\hline
\end{tabular}

Table 4. Effect on infiltration due to 2-year storms for the various NBS Scenarios.

\begin{tabular}{cccccc}
\hline \multirow{2}{*}{ Catchment } & \multirow{2}{*}{$\begin{array}{c}\text { Total infiltration } \\
(\mathrm{mm})\end{array}$} & NBS Scenario 1 & NBS Scenario 2 & NBS Scenario 3 & NBS Scenario 4 \\
\cline { 3 - 6 } & 7.49 & $-0.5 \%$ & $20.8 \%$ & $13.7 \%$ & $6.6 \%$ \\
Subarea 1 & 7.49 & $-0.4 \%$ & $21.0 \%$ & $13.9 \%$ & $6.8 \%$ \\
Subarea 2 & 7.49 & $-0.3 \%$ & $23.7 \%$ & $16.4 \%$ & $9.1 \%$ \\
Subarea 3 & 7.49 & $-0.4 \%$ & $21.0 \%$ & $13.9 \%$ & $6.8 \%$ \\
Subarea 4 & 7.49 & $-0.4 \%$ & $21.0 \%$ & $13.9 \%$ & $6.8 \%$ \\
Subarea 5 & 7.49 & $-0.4 \%$ & $21.0 \%$ & $13.9 \%$ & $6.8 \%$ \\
Subarea 6 & 7.49 & $-0.4 \%$ & $21.4 \%$ & $14.3 \%$ & $7.1 \%$ \\
System area & & & & & \\
\hline
\end{tabular}


Table 5. Effect on evaporation due to 2-year storms for the various NBS Scenarios.

\begin{tabular}{|c|c|c|c|c|c|}
\hline \multirow{2}{*}{ Catchment } & \multirow{2}{*}{$\begin{array}{c}\text { Total } \\
\text { evaporation } \\
\text { (CMS) }\end{array}$} & \multicolumn{4}{|c|}{ Change in total evaporation } \\
\hline & & NBS Scenario 1 & NBS Scenario 2 & NBS Scenario 3 & NBS Scenario 4 \\
\hline Subarea 1 & 0.82 & $-6.3 \%$ & $-47.7 \%$ & $-31.4 \%$ & $-15.5 \%$ \\
\hline Subarea 2 & 0.68 & $-6.5 \%$ & $-47.7 \%$ & $-31.3 \%$ & $-15.5 \%$ \\
\hline Subarea 3 & 5.76 & $-6.1 \%$ & $-52.1 \%$ & $-36.2 \%$ & $-20.5 \%$ \\
\hline Subarea 4 & 4.59 & $-6.1 \%$ & $-49.4 \%$ & $-32.8 \%$ & $-16.4 \%$ \\
\hline Subarea 5 & 2.78 & $-6.1 \%$ & $-49.7 \%$ & $-33.1 \%$ & $-16.5 \%$ \\
\hline Subarea 6 & 1.58 & $-9.3 \%$ & $-49.6 \%$ & $-33.0 \%$ & $-16.5 \%$ \\
\hline System area & 6.65 & $-4.2 \%$ & $-41.9 \%$ & $-27.8 \%$ & $-13.8 \%$ \\
\hline
\end{tabular}

with DCD 20.

\subsection{Discussion of Results}

Under scenario 1, runoff volume and peaks reduction of the range of $6.1 \%$ to $9.4 \%$ are achieved among the six subareas considered in Francistown. For scenario 2, 3 and 4, more reductions in runoff in the order of $20 \%$ to $40 \%$ are prevalent. It is within the expected range as more measures to decrease in surface runoff coefficient and imperviousness would reduce runoff substantially.

In the entire drainage area, runoff reductions in between $5.3 \%$ and $46.0 \%$ can be evident for the four NBS scenarios. It is evident that as more measures to decrease infiltration and increase runoff coefficient are introduced, more urban runoff will be generated with implications to creating surface storage sites, and also for controlling increases in wet weather flow into the sewerage systems.

Generally, the changes in runoff storages and peaks as well evaporation and infiltration for the 2-year and 10-year recurrence interval storms are different slightly. This is due to changes of rainfall intensities used for the two cases. This is an indication that these measures if introduced in the short term, say within 2 years, the effect of reductions in runoff volumes and peaks well be equally advantageous in improving urban water management strategies. However, the scale of introducing these measures and economy impact as well as budgetary constraints may hinder for these objective to be achieved as quickly as practicable. However, in the long-term, as stipulated in the 10-years simulation results, substantial effective management of urban water and excess stormwater can be achieved if well planned and coordinated actions can be implemented to improve the drainage situation of the study area.

However, the tradeoff between benefit of creating urban aquatic environment created from runoff generated at selected spots versus the reduction in runoff on wet weather flow rates, sewer capacities, wastewater treatment effluent and downstream polishing wetlands should be critically evaluated. 


\subsection{Implications for Implementing NBS at Urban Scale}

Urban sewerage and storm management investments are considered as part of the water supply and grey water/sanitation, and urban road infrastructure sector, respectively. In the drinking water supply and sanitation sector as a whole, NBS appear to be severely underfunded in comparison with grey infrastructure.

In the case of the City of Francistown, a great opportunity exists to harness the excess runoff generated at different localities/watershed outlets as described in the modelling study. Furthermore, the effluent from wastewater treatment plant can be stored in wetlands and be used to create more ecological and agricultural reuse opportunities.

The case of a similar experience from Gaborone shows that an irrigation and ecologically sustainable environment can be created. The case in point is the Glen valley wetlands and their use for irrigation which is well managed by the Ministry of Agriculture and Food Security (Figure 8). If efficient management of the irrigation system is achieved, the site is of great importance in demonstrating effective urban water management. Furthermore, measures taken also can be used as a demonstration to enhance grey infrastructure with green infrastructure and to judge cost-effectiveness while providing substantial co-benefits for the local communities and urban youth employment creation.

Artificial recharge potential and some positive and negative impacts of use of treated wastewater is another important dimension to consider in arid environments. Constructed wetlands and their impacts of treated wastewater on the surface water and groundwater quality around Glen Valley wastewater treatment

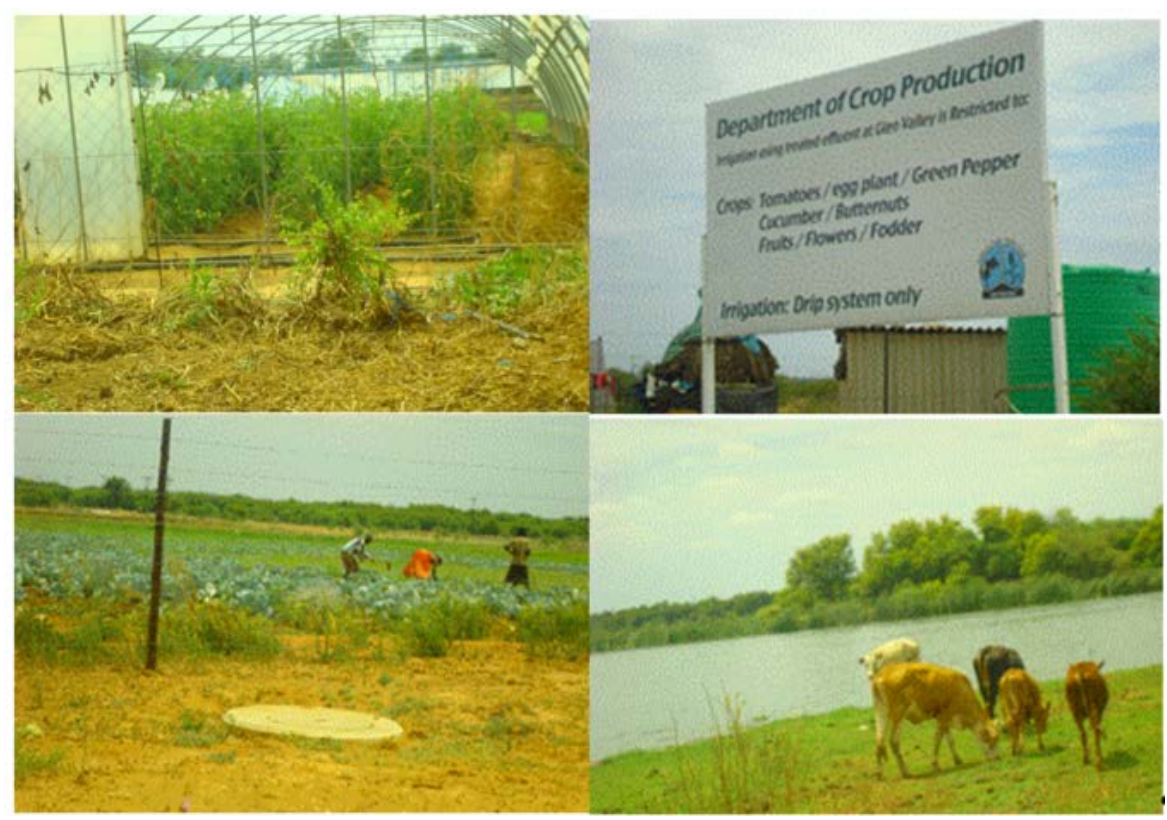

Figure 8. Urban water management through NBS and periurban agricultural reuse of water in constructed wetland system downstream of urban wastewater treatment facility in the Glen Valley area of Gaborone, Botswana. 
facility is provided in [62].

\section{NBS Implementation Strategies in Africa}

\subsection{Context of Implementation}

In the context of water and sanitation, constructed wetlands for wastewater treatment can be a cost-effective NBS that provides effluent of adequate quality for several non-potable uses, including irrigation, as well as offering additional benefits, including energy production [1]. With over $80 \%$ of all wastewater released to the environment without any prior treatment globally, and over $95 \%$ in some developing countries [1], constructed wetlands can provide great opportunities for communities of all sizes and regions in Africa and beyond.

Effectively collected urban runoff in drainage systems in combined sewerage systems or wet weather flows in sewerage networks can be used in the nature based solutions in the following manner:

- reuse of wastewater for urban and peri-urban agriculture.

- reuse of wastewater for urban landscaping and gardening.

- constructed wetlands as cooling of urban runoff.

- constructed wetlands, ecological benefits and reuse in aquaculture.

- artificial groundwater recharge as wastewater reuse.

Moreover efficiently built wastewater treatment facilities can have advantages in downstream nature based solutions and co-benefits of:

- nutrient recycling and sludge reuse.

- phosphorus recovery and reuse from wastewater.

- sustainable energy generation as reuse.

\subsection{Context of Implementation}

The biological and geophysical characteristics of a river basin directly affect the quantity and quality of water flowing downstream over time and space. Any significant changes in the characteristics of landuse/landcover (LULC) and climate change can alter these hydrological features. Improved land management can therefore be seen to include an ensemble of NBS that can collectively enhance water security. There are examples of such practices across different regions.

Figure 9 shows a framework for identification of water problems and urban pressures and mitigation options by the application of NBS as noted in detail in [2] [39].

Ecosystem-based interventions can be especially advantageous from a transboundary perspective. They rarely have negative transboundary impacts, but instead can have numerous co-benefits for the entire basin, for example through the maintenance and enhancement of ecosystem services crucial for livelihoods and human well-being, such as clean water, water regulation and habitat, recreational opportunities, and food. The UNECE Convention on the Protection and 


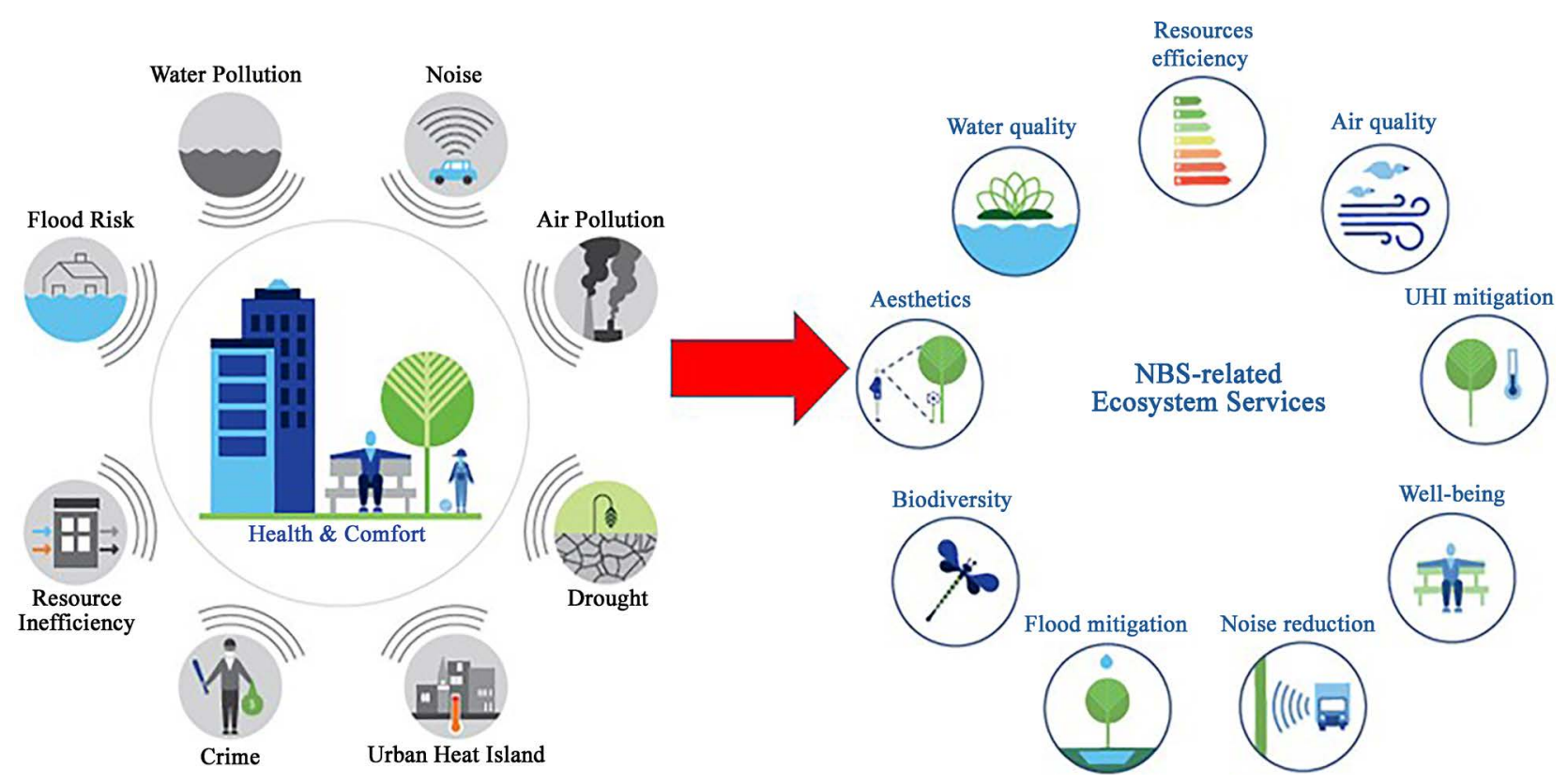

Figure 9. Water problems and urban pressures and mitigation options by the application of NBS [39].

Use of Transboundary Watercourses and International Lakes (the "Water Convention") provides a global legal and intergovernmental framework for supporting transboundary cooperation in promoting NBS. All UN Member States have been able to accede to the Convention since March 2016. The Water Convention itself promotes an ecosystem approach since it obliges Parties to prevent, control and reduce transboundary impacts, ensure conservation and, where appropriate, restore ecosystems. Several ecosystem-based activities have been implemented under the Convention.

Well established transboundary basin organizations in Africa such as those for Orange-Senqu (ORASECOM), Limpopo (LIMCOM), Zambezi (ZAMCOM), Okavango (OKACOM), etc. can also provide pragmatic opportunities for promoting the uptake of NBS among riparian countries.

\subsection{Regional and National Frameworks of NBS}

NBS can merely get focus as a standalone solution in the water supply and sanitation sector unless it is employed as add-on concept and practice to enhance water management, environmental quality and multi-purpose water management in urban and rural settings. Although most often driven by local stakeholders, such as large water users and municipalities, to achieve specific water management outcomes, broader frameworks and partnerships at national and regional levels play a critical role in fostering implementation of NBS. No separate national policies do usually exist to facilitate and oversee implementation of NBS, which is particularly critical, unless it is driven as part of the traditional water-related infrastructure.

Large-scale national-level implementation of NBS as part of a broader policy framework is required for achieving a specific water management objective-in 
this case flood management-with complementary objectives such as spatial planning and environmental protection. Figure 10 shows the framework for evolving approaches to the water-ecosystem nexus where emphasis has shifted from looking at impacts on ecosystems to managing ecosystems to achieve water management objectives.

NBS provide a mechanism for realizing participatory approaches to water and land use management, facilitating the exchange of information and in some cases drawing upon traditional knowledge and historically tested natural resource management approaches, such as the Integrated water resources management (IWRM) approach. They can assist in formalizing and activating partnerships among disparate groups at the community level, including national and local government, local stakeholders and community-based organizations, the private sector, and donor agencies, thus empowering community members to implement, monitor and report on investments, successes and lessons

OLD APPROACHES:

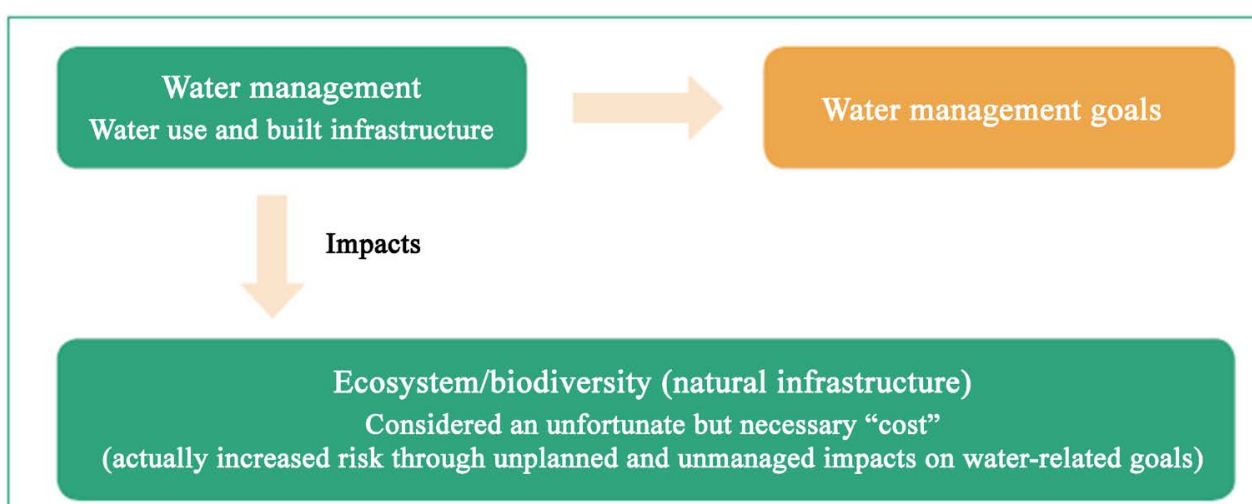

NEW PARADIGM:

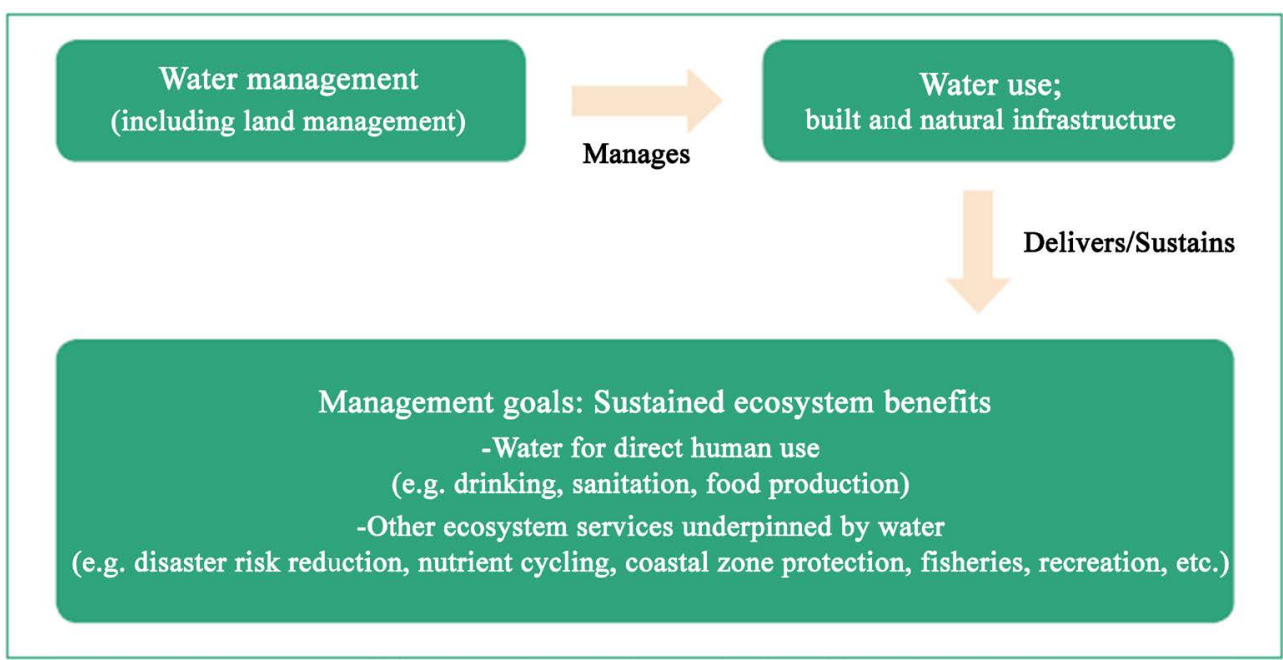

Source: [2] [63].

Figure 10. Water problems and urban pressures and mitigation options by the application of NBS. 
learned.

Although many relevant frameworks either mandate or enable NBS to be considered, the final decisions will often depend on a more detailed consideration of the costs and benefits of various options. A notable feature of recent legal/regulatory/framework development is their emphasis (whether legally mandated or not) that all benefits, and not just a narrow set of hydrological outcomes, need to be factored into assessment of investment options. This requires a detailed systematic approach to evaluating costs and benefits, which is possible and will lead to improved decision making and overall system performance [1].

\subsection{Implementing NBS at National Levels}

A significant advantage of rehabilitating and protecting functioning ecosystems is the multiple additional benefits that ecosystems provide when compared to single-purpose built infrastructure installations. The South Africa 2013 National Water Resources Strategy explicitly considers ecological and built infrastructure as mutually supportive elements of an integrated approach to managing water. In South Africa, significant gains in water supply were achieved through ecological infrastructure and, importantly, the increases in baseflow contributed to more valuable dry-season supply [64]. The above only assessed the benefits of investing in ecological infrastructure in terms of water supply (quantity) and reduced sediment loads. Improving ecological infrastructure can also improve water quality, pollination services to adjacent cropland, grazing values, and access to medicinal plants, while reducing flood intensities and damages, removing carbon dioxide from the atmosphere, increasing game and livestock productivity, and providing ecotourism opportunities and improved recreational and cultural spaces [1] [64].

The detailed assessments undertaken, using consistent hydrological and economic comparisons between water resources infrastructure investment options, show that rehabilitating ecological infrastructure could result in improved water security, support built infrastructure and simultaneously provide other benefits, including job creation potential that has not yet been realized and is financially viable and cost-effective [1] [64]. On the other hand, [65] considering the Buffalo catchment in South Africa, noted that there are advantages of maintenance of recession flows in riverine and ecosystems including improvement of baseflows and maintenance of groundwater recharge and water quality. A review of global wastewater and sludge production as a wastewater treatment and use options in the Urbanizing World is provided in [66]. A more specific regional review of wastewater treatment performance efficiency of constructed wetlands in African countries is provided in [67]. In a natural setting, [68] detailed accounts of evaluating the Flow Regulating Functions of Natural Ecosystems in the Zambezi River Basin.

One of the pioneering examples of urban river restoration for urban public park development is the public investment project of Addis Ababa, known as the 
Sheger Park. This is an indicator of emerging African efforts of investing in urban water management through restoration of rivers which can be used to derive co-benefits in public recreation and amenities of artificial aquatic ecosystems through development of urban mass-tourism sites.

In the southern African context, experiences show the benefits and opportunities of nature based solutions in the management of water resources that include:

- Improvement in the understanding and incorporation of climate change and adaptation-induced engineering design and innovations in water development projects in Africa [26].

- Constructed wetlands and their impacts of treated wastewater on the surface water and groundwater quality around Glen Valley wastewater treatment facility [62].

- Understanding of regional design storm and flood modelling with risk implications in ungauged catchments [33] [69].

- Maintenance and management of surface water and groundwater recharge in data scarce arid catchments [70].

- Management of water supply reservoirs and dams through technical and engineering tools under uncertainties in arid and urbanized environments [71].

- Maintenance if recession flows in riverine and ecosystems including improvement of baseflows and maintenance of groundwater recharge and water quality (e.g. [65] [72]) and improvement and management of alluvial aquifers and estimating Hydraulic Properties of Alluvial Sand Aquifer In Motloutse River course focusing on Eastern Botswana [72].

\subsection{Implementing NBS at Southern African Level}

The Southern African Development Community (SADC) region has developed a regional water policy and regional water strategy to promote regional integration and poverty reduction within SADC, which particularly requires and promotes two objectives, namely: 1) Cooperative management of shared watercourses within the region, primarily through the Protocol on Shared Watercourses, and 2) Harmonisation of national water sector management between SADC Member States to facilitate integration and the achievement of endorsed targets.

A regional water policy is developed based on principles and objectives from the Millennium Development Goals, World Summit on Sustainable Development, NEPAD (goals of AMCOW on water) and multi-lateral agreements between Watercourse States. The policy was synthesized to underpin the following policy principles [73].

- Water as an instrument for peace, cooperation and regional integration

- Effective public consultation and involvement of users

- Integrated and people-centered planning including fair compensation for affected parties 
- Development of SADC water resources through the joint planning and construction of storage, in order to rectify historical imbalances and promote water supply for irrigation and poor communities

- Efficient use of water through demand management, conservation and reuse/ recycling, and the efficient use of water in agriculture

- Recognition of the environment as a resource base and a legitimate user of water

- The protection of the environment through appropriate user charges and the enforcement of "the polluter pays" and "waster pays" principles, taking into account equity and social justice

- Integration of water supply, sanitation and hygiene education programs

- Capacity building to ensure that managers of water, waste and sanitation have the requisite knowledge and tools

- Ensuring that waste is safely managed at or as close as possible to the point of generation

- Preventing the import (and export) of harmful waste across the national and regional boundaries

The conceptual framework for the SADC regional water policy presented in Figure 11, which was implemented during the policy formulation to illustrate the linkage to the SADC goals of regional integration and poverty reduction, water at the center domain of developmental in the region. The policy indirectly can be used to embrace on the implementation and use of NBS tools to improve sustainable development and management of the region's water resources.

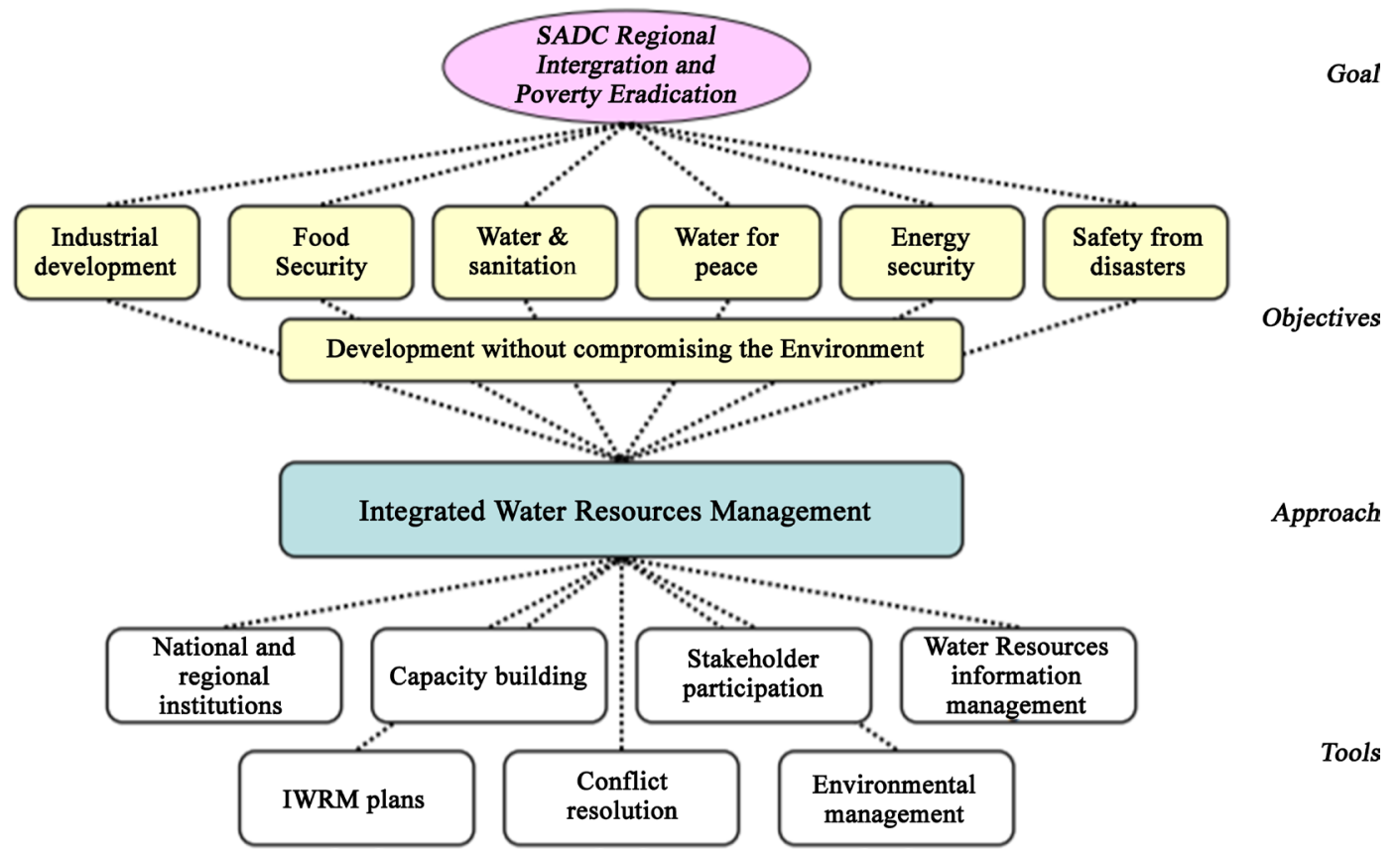

Source: [73].

Figure 11. Conceptual framework of the SADC regional water policy. 
The key water related objectives that can be considered as part of the NBS implementation are linked to industrial development (including agri-businesses), food security, access to water and sanitation, water for peace, energy security and safety from disasters. Underlying these is the objective of sustainable development, or development that does not compromise the environment.

With possible opportunity that can be garnered to promote NBS in the region, the tenets of Integrated water resources management (IWRM) is the fundamental approach that has been adopted in the SADC water policy, which is enabled through the development of tools related to institutional development, capacity building, stakeholder participation, information management, integrated planning, conflict resolution and environmental management. Each of these objectives and tools is addressed in the policy, with IWRM being the common thread that links them all together.

In the context of southern African region, there are a number of experiences which show the benefits and opportunities of nature based solutions in the management of water resources. These efforts found in the region are also highlighted in related publications that include:

- Improved understanding of agricultural water management such as climate change impacts and adaptation in rainfed farming systems through improved modeling frameworks for scaling-out climate smart agriculture in Sub-Saharan Africa as noted in [74].

- Improved understanding and evaluation of drought Severity, drought regimes and impacts at a basin scale in the Limpopo basin as described in [75] [76].

- Assessment of Sedimentation Impacts on Small Dams at a basin scale such as A Case of Small Reservoirs in the Lotsane Catchment of the Limpopo Basin [77].

- Managing flooding and flood frequency under changing climate at a basin scale in the upper Kafue catchment, in the Zambezi River Basin of Southern Africa through application of a large scale hydrological model [78].

- Evaluation of evapotranspiration at regional scale based on the FAO Penman-Montheith, Priestly-Taylor and Hargreaves models for estimating reference evapotranspiration at a regional scale in southern Malawi [79].

- Hydrological Modeling of Large Drainage Basins using a GIS-based Hybrid Atmospheric and Terrestrial Water Balance (HATWAB) Model through application in the Lmpopo basin that drains four countries of Southern Africa including parts of Botswana, Zimbabwe, South Africa and Mozambique [80].

The various modelling efforts and water resources assessments can be utilized to further assess the impact of various NBS and measures associated with NBS to effectively manage the water resources of the various basins in different parts of southern Africa.

\subsection{Challenges and Limitations}

Implementation and provision of NBS often require cooperation among mul- 
tiple institutions and stakeholders, something that can be difficult to achieve. There are no clear institutional arrangements that evolve with cooperation on NBS in mind apart from the traditional project level, ad-hoc collaborators for project implementation, mostly on projects that indirectly focus on NBS. There is a lack of awareness, communication and knowledge at all levels, from communities to regional planners and national policy makers, of what NBS can really offer beyond the physical infrastructure and environmental aspects, especially in the developing world.

A number of factors can contribute to the lack of focus and attention required to implement NBS as part of the business-as-usual mode of practice along with urban planning, stormwater management and wastewater treatment and reuse. The situation can be compounded by a lack of understanding of how to integrate green and grey infrastructure at scale, and an overall lack of capacity to implement NBS in the context of water [1]. Lack of the understanding and myths and/or uncertainty remain about the functioning of natural or green infrastructure, and about what ecosystem services and their benefit mean in practical terms. Additional factors also include [1]:

- It is also not entirely clear, at times, what constitutes a NBS.

- There is a lack of technical guidance, tools and approaches to determine the right mix of NBS and grey-infrastructure options.

- The hydrological functions of natural ecosystems, like wetlands and floodplains, are much less understood than those provided by grey infrastructure.

- NBS are even more neglected in policy appraisal and in natural resource and development planning and management.

- Insufficient research and development in NBS and lack of robust assessments of current NBS experience, especially in terms of their hydrological performance, and cost-benefit analyses in comparison or conjunction with grey solutions, especially in the developing world.

- There are limits to what ecosystems can achieve and these need much better identification. For example, "tipping points", beyond which negative ecosystem change becomes irreversible, are well theorized but rarely quantified.

- The high degree of variation in the impacts of ecosystems on hydrology (depending on ecosystem type or subtype, location and condition, climate and management) cautions to avoid generalized assumptions about NBS. For example, trees can increase or decrease groundwater recharge according to their type, density, location, size and age.

- Natural systems are dynamic and their roles and impacts change over time.

- Understanding of cost-effectiveness of NBS and including consideration of co-benefits. While some small-scale NBS applications can be low- or no-cost, some applications, particularly at scale, can require large investments.

- Ecosystem restoration costs, for example, can vary widely from a few hundred to several millions of US dollars per hectare. Site-specific knowledge on the field deployment of NBS is essential yet often inadequate. 
With more attention given to NBS and more knowledge and practices are understood, NBS practitioners need to greatly increase knowledge to support decision making in considering NBS in projects that are directly or indirectly associated with NBS.

\subsection{Enabler Conditions for uptake of NBS}

A number of enabling conditions to accelerate uptake of NBS can be considered equitably alongside other options for water resources management. According to the compendium of experience of [1], the required responses to these challenges essentially involve creating enabling conditions for NBS to be considered include the following:

Leveraging financing-NBS do not necessarily require additional financial resources but usually involve redirecting and making more effective use of existing financing. Investments in green infrastructure are being mobilized thanks to the increasing recognition of the potential of ecosystem services to provide system-wide solutions that make investments more sustainable and cost-effective over time.

Creating an enabling regulatory and legal environment-The vast majority of current regulatory and legal environments for water management were developed largely with grey-infrastructure approaches in mind. Consequently, it can often be challenging to retrofit NBS into this framework. However, rather than expecting drastic changes in regulatory regimes, much can be achieved by promoting NBS more effectively through existing frameworks.

Improving cross-sectoral collaboration-NBS can require much greater levels of cross-sectoral and institutional collaboration than grey-infrastructure approaches, particularly when applied at landscape scale. However, this can also open opportunities to bring those groups together under a common approach or agenda.

Improving the knowledge base-Improving the knowledge base on NBS, including in some cases through more rigorous science, is an essential overarching requirement. Established evidence helps convince decision makers of the viability of NBS. For example, a frequently raised concern is that NBS take a long time to achieve their impact, implying that grey infrastructure is quicker. However, the evidence shows that this is not necessarily the case and timescales to deliver benefits can compare favorably to those of grey-infrastructure solutions.

Using the 2030 Agenda for Sustainable Development as entry point-NBS offer high potential to contribute to the achievement of most of the targets of SDGs (Sustainable Development Goals), SDG 6 (on water). Areas in which this contribution translates into particularly striking positive direct impacts on other SDGs are with regards to water security for underpinning sustainable agriculture (SDG 2), healthy lives (SDG 3), building resilient (water-related) infrastructure (SDG 9), sustainable urban settlements (SDG 11) and disaster risk reduction (SDG 11 and, as related to climate change, SDG 13). 


\section{Conclusions}

Reducing the impervious percentage could contribute to alleviating the flood situation of the City of Francistown urban development area. Future development should try to maintain per cent imperviousness to reduce in the order of $30 \%$ to $40 \%$ or less, assuming no other interventions (e.g. SUDS) is considered.

The findings of this study also concur with similar efforts made in investment of urban green infrastructure, from the revegetation of impermeable surfaces to green roofs and constructed wetlands, which can yield positive results in terms of water availability, water quality and flood reduction, as exemplified by China's experience of the "sponge city" project [24].

Reduction in runoff could positively impact in reduction of wet weather flow rates joining the sewerage networks and loads at the wastewater treatment facilities. The effluent polishing wetlands downstream of wastewater treatment plants could also be further used for agricultural purposes. The excess runoff generated at watershed outlets could be used to create urban amenities and containment of large suspended materials in runoff. Furthermore, a balance should be stricken between runoff generated during storm events and the wet weather flows for creating sustainable, cost-effective and efficient urban water and sanitation infrastructure.

National development plans should embrace sustainable urban development plans as one of their agenda in promoting sustainable water development investment and management in urban and rural catchments. For instance, the Botswana Vision 2036 as a transformational agenda considers sustainable environment as one focus area. Pillar 3 of the agenda is sustainable environment with holistic objectives encompassing sustainable natural resources management, water security, energy security, ecosystems functions \& services, sustainable human settlement, sustainable landuse, climate resilience and disaster risk reduction, and pollution \& waste management [81].

The social investment and development in these areas will help achieve the global development agendas constituted in agenda 11 of the sustainable development goals (SDGs), "Make cities and human settlements inclusive, safe, resilient and sustainable" (United Nations, 2015). Consideration of urban water management through efficient collection and treatment systems will help to sustain some of the green infrastructure requirements. This will further help nations to achieving the national development agenda and the Sustainable Development Goals (SDGs) through investment in ecological infrastructure [27].

The drinking water supply and sanitation sector as a whole, NBS appear to be severely underfunded in comparison with grey infrastructure since NBS as components of sewerage and storm management investments are considered as mere aspects of environmental management in water supply and grey water/sanitation, and urban road infrastructure investments. This challenge remains at large in the developing world and with dividends envisioned in co-benefit appraisal of NBS investments, the future trajectory of adoption and implementation in urban 
and rural water management investments remain at large.

\section{Acknowledgements}

The authors wish to appreciate the support of the University of Botswana and Department of Metrological Services, Water Utilities Corporation and Department of Water Affairs of the Botswana Government for encouraging this research directly or indirectly by providing the necessary information and support.

\section{Conflicts of Interest}

The authors declare no conflicts of interest regarding the publication of this paper.

\section{References}

[1] WWAP (United Nations World Water Assessment Programme)/UN-Water (2018) The United Nations World Water Development Report 2018: Nature-Based Solutions for Water. UNESCO, Paris, 139.

[2] Oral, H.V., Carvalho, P., Gajewska, M., Ursino, N., Masi, F., van Hullebusch, E.D., Kazak, J.K., Exposito, A., Cipolletta, G., Andersen, T.R., Finger, D.C., Simperler, L., Regelsberger, M., Rous, V., Radinja, M., Buttiglieri, G., Krzeminski, P., Rizzo, A., Dehghanian, K., Nikolova, M. and Zimmermann, M. (2020) A Review of NatureBased Solutions for Urban Water Management in European Circular Cities: A Critical Assessment Based on Case Studies and Literature. Blue-Green Systems, 2, 112 136. https://doi.org/10.2166/bgs.2020.932

[3] Zhang, C., Wang, Y. and Ding, W. (2017) Vulnerability Analysis of Urban Drainage Systems: Tree vs. Loop Networks. Sustainability, 9, 397. https://doi.org/10.3390/su9030397

[4] Dietz, M.E. (2015) Low Impact Development Practices: A Review of Current Research and Recommendations for Future Directions. Water, Air, \& Soil Pollution, 186, 351-363. https://doi.org/10.1007/s11270-007-9484-Z

[5] Cheng, M.S., Coffman, L., Riverson, J., Shen, J., Ouyang, J., Lahlou, M. and Shoemaker, L. (2002) Low-Impact Development Management Practices Evaluation Computer Module. WEFTEC, 2002, 1522-1534.

[6] Dietz, M.E. (2007) Low Impact Development Practices: A Review of Current Research and Recommendations for Future Directions. Water, Air, and Soil Pollution, 186, 351-363. https://doi.org/10.1007/s11270-007-9484-Z

[7] Yu, K.J. and Li, D.H. (2015) Sponge City Theory and Practice. Journal of CCPR, 39, 26-36

[8] David, R.M., Magnus, M., Stephen, C. and David, J.B. (2013) Towards Sustainable Urban Water Management: A Critical Reassessment. Water Research, 47, 71507161. https://doi.org/10.1016/j.watres.2013.07.046

[9] Wong, T.H.F. (2006) Water Sensitive Urban Design-The Journey Thus Far. Australasian Journal of Water Resources, 10, 213-222. https://doi.org/10.1080/13241583.2006.11465296

[10] Davis, M.K. and Naumann, S. (2017) Chapter 8. Making the Case for Sustainable Urban Drainage Systems as a Nature-Based Solution to Urban Flooding. In: Kabisch, N., et al., Eds., Nature-Based Solutions to Climate Change Adaptation in Urban Areas, Theory and Practice of Urban Sustainability Transitions, Springer, 123- 
137. https://doi.org/10.1007/978-3-319-56091-5_8

[11] Nordeidet, B., Nordeide, T., Asteb $\Phi$ l, S.O. and Hvitved, J.T. (2004) Prioritising and Planning of Urban Stormwater Treatment in the Alna Watercourse in Oslo. Science of the Total Environment, 334-335, 231-238.

https://doi.org/10.1016/j.scitotenv.2004.04.040

[12] Zhou, Q. (2014) A Review of Sustainable Urban Drainage Systems Considering the Climate Change and Urbanization Impacts. Water, 6, 976-992.

https://doi.org/10.3390/w6040976

[13] Brown, R.R., Keath, N. and Wong, T.H.F. (2009) Urban Water Management in Cities: Historical, Current and Future Regimes. Water Science \& Technology, 59, 847855. https://doi.org/10.2166/wst.2009.029

[14] Matthew, G. (2004) Rethinking Urban Metabolism: Water, Space and the Modern City. City, 8, 363-379. https://doi.org/10.1080/1360481042000313509

[15] He, B.J., Zhu, J., Zhao, D.X., Gou, Z.H., Qi, J.D. and Wang, J. (2019) Co-Benefits Approach: Opportunities for Implementing Sponge City and Urban Heat Island Mitigation. Land Use Policy, 86, 147-157.

https://doi.org/10.1016/j.landusepol.2019.05.003

[16] Li, Y.X., Kang, J.-H., Lau, S.-L., Kayhanian, M. and Stenstrom, M.K. (2008) Optimization of Settling Tank Design to Remove Particles and Metals. Journal of Environmental Engineering, 134, 885-894. https://doi.org/10.1061/(ASCE)0733-9372(2008)134:11(885)

[17] Cadenasso, M.L. and Pickett, S.T.A. (2008) Urban Principles for Ecological Landscape Design and Management: Scientific Fundamentals. Cities and the Environment, 1, Article 4: 1-16. https://doi.org/10.15365/cate.1242008

[18] Lim, H.S. and Lu, X.X. (2016) Sustainable Urban Stormwater Management in the Tropics: An Evaluation of Singapore's ABC Waters Program. Journal of Hydrology, 538, 842-862. https://doi.org/10.1016/j.jhydrol.2016.04.063

[19] AstebФ1, S.O., HvitvedJacobsen, T. and Simonsen, Ф.O. (2004) Sustainable Stormwater Management at Fornebu-From an Airport to an Industrial and Residential Area of the City of Oslo, Norway. Science of the Total Environment, 334-335, 239-249. https://doi.org/10.1016/j.scitotenv.2004.04.042

[20] Jones, P. and Macdonald, N. (2007) Making Space for Unruly Water: Sustainable Drainage Systems and the Disciplining of Surface Runoff. Geoforum, 38, 534-544. https://doi.org/10.1016/j.geoforum.2006.10.005

[21] Norton, B.A., Coutts, A.M., Livesley, S.J., Harris, R.J., Hunter, A.M. and Williams, N.S.G. (2015) Planning for Cooler Cities: A Framework to Prioritise Green Infrastructure to Mitigate High Temperatures in Urban Landscapes. Landscape and Urban Planning, 134, 127-138. https://doi.org/10.1016/j.landurbplan.2014.10.018

[22] Charlesworth, S.M. (2010) A Review of the Adaption and Mitigation of Global Climate Using Sustainable Drainage Cities. Journal of Water and Climate Change, 1, 165-180. https://doi.org/10.2166/wcc.2010.035

[23] Wang, R.S., Li, F., Hu, D. and Li, B.L. (2011) Understanding Eco-Complexity: Social-Economic-Natural Complex Ecosystem Approach. Ecological Complexity, 8, 15-29. https://doi.org/10.1016/j.ecocom.2010.11.001

[24] Wu, D.J., Zhan, S.Z. and Li, Y.H. (2016) Research on the Emerging Trend and Practice of Chinese Characteristic Sponge Cities. China Soft Science, 1, 79-97.

[25] Matondo, J., Alemaw, B.F. and Sandwidi, J.P. (2020) Climate Variability and Change Research in Africa-Perspectives and Experiences. Sustainable Development Goals Series. Springer Nature Switzerland AG. https://doi.org/10.1007/978-3-030-31543-6 
[26] Alemaw, B.F. and Sebusang, N.M. (2019) Climate Change and Adaptation-Induced Engineering Design and Innovations in Water Development Projects in Africa. African Journal of Science, Technology, Innovation and Development, 11, 197-209. https://doi.org/10.1080/20421338.2017.1355601

[27] Cumming, T.L., Shackleton, R.T., Förster, J., Dini, J., Khan, A., Gumula, M. and Kubiszewski, I. (2017) Achieving the National Development Agenda and the Sustainable Development Goals (SDGs) through Investment in Ecological Infrastructure: A Case Study of South Africa. Ecosystem Services, 27, 253-260. https://doi.org/10.1016/j.ecoser.2017.05.005

[28] MTC (2018) Hydrology and Road Drainage Manual. Ministry of Transport and Communication, Roads Department.

[29] DTRP (2013) Development Control Code. Department of Town and Regional Planning, Government of Botswana, 324.

[30] SANRAL (2013) Road Drainage Manual. 6th Edition, SANRAL-South African National Roads Agency Limited, Pretoria, RSA.

[31] DTRP (2011) Greater Francistown Planning Area Structure Plan (1997-2021) Ministry of Lands and Housing. Department of Town and Regional Planning in Collaboration with Francistown City Council.

[32] Silveira, A.L.L. (2016) Cumulative Equations for Continuous Time Chicago Hyetograph Method. Brazilian Journal of Water Resources, 21, 646-651. https://doi.org/10.1590/2318-0331.011615094

[33] Alemaw, B.F. and Chaoka, T.R. (2016) Regionalization of Rainfall Intensity-Duration-Frequency (IDF) Curves in Botswana. Journal of Water Resource and Protection, 8, 1128-1144. https://doi.org/10.4236/jwarp.2016.812088

[34] The Voice (2014) Images of the Ongoing Flooding in Some Areas of Francistown City. The Voice Newspaper Botswana, February 7, 2014. https://www.facebook.com/TheVoiceBW/posts/10152082546419086

[35] Gujer, W., Krejci, V., Schwarzenbach, R. and Von der Zobrist, J. (1982) Kanalisation ins Grundwasser Charakterisierung eines Regenereignisses im Glattal. GWF, 62, 298-311.

[36] Hauger, M.B., Rauche, W., Linde, J.J. and Mikkelsen, P.S. (2002) Cost Benefit Risk-A Concept for Management of Integrated Urban Wastewater Systems. Water Science \& Technology, 45, 185-193. https://doi.org/10.2166/wst.2002.0078

[37] Morison, P.J. and Brown, R.R. (2011) Understanding the Nature of Publics and Local Policy Commitment to Water Sensitive Urban Design. Landscape and Urban Planning, 99, 83-92. https://doi.org/10.1016/j.landurbplan.2010.08.019

[38] Brown, R., Keath, N. and Wong, T. (2009) Urban Water Management in Cities: Historical, Current and Future Regimes. Water Science and Technology, 59, 847-855. https://doi.org/10.2166/wst.2009.029

[39] Blue Green Solutions (2017) A Systems Approach to Sustainable, Resilient and CostEfficient Urban Development, March 2017, Technical Report.

[40] Eroksuz, E. and Rahman, A. (2010) Rainwater Tanks in Multi-Unit Buildings: A Case Study for Three Australian Cities. Resources Conservation Recycling, 54, 14491452. https://doi.org/10.1016/j.resconrec.2010.06.010

[41] Kim, R.H., Lee, S., Kim, Y.M., Lee, J.H., Kim, S.K. and Kim, J.G. (2005) Pollutants in Rainwater Runoff in Korea: Their Impacts on Rainwater Utilization. Environment Technology, 26, 411-420. https://doi.org/10.1080/09593332608618546

[42] City of Toronto (2009) Riversides. Rainwater Harvesting, Energy Conservation and 
Greenhouse Gas Emission Reductions in the City of Toronto. http://www.toronto.ca/taf/pdf/riversides-080709.pdf

[43] Berndtsson, J.C. (2010) Green Roof Performance towards Management of Runoff Water Quantity and Quality: A Review. Ecological Engineering, 36, 351-360. https://doi.org/10.1016/j.ecoleng.2009.12.014

[44] Ghani, A.B., Zakaria, N.A., Abdulla, R., Yusof, M.F., Moh Sidek, L., Kassim, A.H. and Ainan, A. (2004) Bio-Ecological Drainage Systems (BIOECODS): Concept, Design and Construction. Proceedings of the 6 th International Conference on Hydro-science and Engineering (IHCE-204), Brisbane.

[45] Bengtsson, L., Grahn, L. and Olsson, J. (2005) Hydrological Function of a Thin Extensive Green Roof in Southern Sweden. Hydrology Research, 36, 259-268.

https://doi.org/10.2166/nh.2005.0019

[46] Mentens, J., Raes, D. and Hermy, M. (2006) Greenroofs as a Tool for Solving the Rainwater Runoff Problem in the Urbanized 21st Century. Landscape and Urban Planning, 77, 217-226. https://doi.org/10.1016/j.landurbplan.2005.02.010

[47] Fang, C.F. (2008) Evaluating the Thermal Reduction Effect of Plant Layers on Rooftops. Energy and Buildings, 40, 1048-1052.

https://doi.org/10.1016/j.enbuild.2007.06.007

[48] Simmons, M.T., Gardiner, B., Windhager, S. and Tinsley, J. (2008) Green Roofs Are Not Created Equal: The Hydrologic and Thermal Performance of Six Different Extensive Green Roofs and Reflective and Nonreflective Roofs in a Sub-Tropical Climate. Urban Ecosystems, 11, 339-348. https://doi.org/10.1007/s11252-008-0069-4

[49] Wong, N.H., Tan, P.Y. and Chen, Y. (2007) Study of Thermal Performance of Extensive Rooftop Greenery Systems in the Tropical Climate. Building Environment, 42, 25-54. https://doi.org/10.1016/S0921-8009(99)00013-0

[50] Brenneisen, S. (2003) The Benefits of Biodiversity from Green Roofs Key Design Consequences. Conference Proceedings of Greening Rooftops for Sustainable Communities, Chicago.

[51] Brenneisen, S. (2006) Space for Urban Wildlife: Designing Green Roofs as Habitats in Switzerland. Urban Habitats, 4, 27-36.

[52] Gedge, D. and Kadas, G. (2005) Green Roofs and Biodiversity. Biologist, 52, 161-169.

[53] Bolund, P. and Hunhammar, S. (1999) Analysis of Ecosystems in Urban Areas. Ecological Economics, 29, 293-301. https://doi.org/10.1016/S0921-8009(99)00013-0

[54] Marsalek, J. and Schreier, H. (2009) Innovation in Stormwater Management in Canada: The Way Forward. Water Quality Research Journal of Canada, 44, 5-10. https://doi.org/10.2166/wqri.2009.001

[55] Philip, R., Anton, B. and Van der Steen, P. (2011) SWITCH Training Kit: Integrated Urban Water Management in the City of the Future. SWITCH Project. http://www.switchurbanwater.eu

[56] Silveira, A.L.L. (2001) Problems of Urban Drainage in Developing Countries. In: International Conference on Innovative Technologies in Urban Storm Drainage, Novatech 2001, Lyon.

[57] Brattebo, B.O. and Booth, D.B. (2003) Long-Term Stormwater Quantity and Quality Performance of Permeable Pavement Systems. Water Research, 37, 4396-4376. https://doi.org/10.1016/S0043-1354(03)00410-X

[58] James, W. and Verspagen, B. (1997) Thermal Enrichment of Stormwater by Urban Pavement. In: James, W., Ed., Advances in Modeling the Management of Stormwater Impacts, CHI, Guelph, 5: Ch. 8. https://doi.org/10.14796/JWMM.R195-08 
[59] Pataki, D.E., Carreiro, M.M., Cherrier, J., Grulke, N.E., Jennings, V., Pincetl, S., Pouyat, R.V., Whitlow, T.H. and Zipperer, W.C. (2011) Coupling Biogeochemical Cycles in Urban Environments: Ecosystem Services, Green Solutions, and Misconceptions. Frontiers in Ecology and the Environment, 9, 27-36.

https://doi.org/10.1890/090220

[60] Drake, J.A.P. and Bradford, A. (2013) Assessing the Potential for Rehabilitation of Surface Permeability Using Regenerative Air and Vacuum Sweeping. In: James, W., Irvine, K., Joksimovic, D., Li, J.Y., McBean, E.A., Pitt, R.E., Vasconcelos, J.G., Wright, S.J. and Wu, J.S., Eds., Pragmatic Modeling of Urban Water Systems, Monograph 21, CHI, Guelph, Ch 16. https://doi.org/10.14796/JWMM.R246-16

[61] US EPA (2000) Low-Impact Development (LID): A Literature Review (Report). 35.

[62] Tshepo, K., Tafesse, N., Chaoka, T.R., Alemaw, B.F. and Laletsang, K. (2017) Impacts of Treated Wastewater on the Surface Water and Groundwater Quality: A Case Study in North East Gaborone, Botswana. Asian Review of Environmental and Earth Sciences, 41, 36-45.

[63] Coates, D. and Smith, M. (2012). Natural Infrastructure Solutions for Water Security. In: Ardakanian, R. and Jaeger, D., Eds., Water and the Green Economy: Capacity Development Aspects, UN-Water Decade Programme on Capacity Development (UNWDPC), Bonn, 167-188.

[64] Mander, M., Jewitt, G., Dini, J., Glenday, J., Blignaut, J., Hughes, C., Marais, C., Maze, K., Van der Waal, B. and Mills, A. (2017) Modelling Potential Hydrological Returns from Investing in Ecological Infrastructure: Case Studies from the Baviaanskloof-Tsitsikamma and uMngeni Catchments, South Africa. Ecosystem Services, 27, 261-271. https://doi.org/10.1016/j.ecoser.2017.03.003

[65] Owolabi, S.T., Madi, K., Kalumba, A.M. and Alemaw, B.F. (2020) Assessment of Recession Flow Variability and the Surficial Lithology Impact: A Case Study of Buffalo River Catchment, Eastern Cape, South Africa. Environmental Earth Sciences, 79, Article No.: 187. https://doi.org/10.1007/s12665-020-08925-4

[66] Sagasta, M.J., Raschid-Sally, L. and Thebo, A. (2015) Global Wastewater and Sludge Production: Treatment and Use. In: Drechsel, P., Qadir, M. and Wichelns, D., Eds., Wastewater. Economic Asset in an Urbanizing World, Springer, Dordrecht, 15-38. https://doi.org/10.1007/978-94-017-9545-6_2

[67] Mekonnen, A., Leta, S. and Njau, K.N. (2015) Wastewater Treatment Performance Efficiency of Constructed Wetlands in African Countries: A Review. Water Science and Technology, 71, 1-8. https://doi.org/10.2166/wst.2014.483

[68] McCartney, M., Cai, X. and Smakhtin, V. (2013) Evaluating the Flow Regulating Functions of Natural Ecosystems in the Zambezi River Basin. IWMI Research Reports Series No. 148. International Water Management Institute (IWMI), Colombo. https://doi.org/10.5337/2013.206

[69] Alemaw, B.F. and Chaoka, R.T. (2016) Regional Design Storm and Flood Modelling-Risk Implications in Ungauged Catchments. Journal of Water Resource and Protection, 8, 1211-1221. https://doi.org/10.4236/jwarp.2016.813093

[70] Tafesse, N., Gebrehiwet, M., Habtu, S. and Alemaw, B.F. (2018) Water Balance Model: Implications for Groundwater Recharge Estimation in Data Scarce Arid Catchment, Northern Ethiopia. Asian Review of Environmental and Earth Sciences, 5, 34-46. https://doi.org/10.20448/journal.506.2018.51.34.46

[71] Alemaw, B.F., Keaitse, E.O. and Chaoka, T.R. (2016) Management of Water Supply Reservoirs under Uncertainties in Arid and Urbanized Environments. Journal of Water Resource and Protection, 8, 990-1009.

https://doi.org/10.4236/jwarp.2016.811080 
[72] Keaitse Edwin, Alemaw B.F, Laletsang K, Tafesse N (2017) Estimating Hydraulic Properties of Alluvial Sand Aquifer in Motloutse River Course, Eastern Botswana. Asian Review of Environmental and Earth Sciences, 4, 28-35. https://doi.org/10.20448/journal.506.2017.41.28.35

[73] SADC (2007) SADC Regional Water Strategy. SADC Secretariat, Gaborone, p. 74.

[74] Alemaw, B.F. and Simalenga, T. (2015) Climate Change Impacts and Adaptation in Rainfed Farming Systems: A Modeling Framework for Scaling-Out Climate Smart Agriculture in Sub-Saharan Africa. American Journal of Climate Change, 4, 313-329. https://doi.org/10.4236/ajcc.2015.44025

[75] Alemaw, B.F. and Kileshye-Onema, J.-M. (2014) Evaluation of Drought Regimes and Impacts in the Limpopo Basin. Hydrology and Earth System Sciences Discussion, 11, 199-222. https://doi.org/10.5194/hessd-11-199-2014

[76] Alemaw, B.F., Kileshye-Onema, J.-M. and Love, D. (2013) Regional Drought Severity Assessment at a Basin Scale in the Limpopo Drainage System. Journal of Water Resource and Protection, 5, 1110-1116. https://doi.org/10.4236/jwarp.2013.511116

[77] Alemaw, B.F., Majauale, M. and Simalenga, T. (2013) Assessment of Sedimentation Impacts on Small Dams-A Case of Small Reservoirs in the Lotsane Catchment. Journal of Water Resource and Protection, 5, 1127-1131. https://doi.org/10.4236/jwarp.2013.512118

[78] Ngongondo, C.S., Li, L., Gong, L.B., Xu, C.-Y. and Alemaw, B.F. (2013) Flood Frequency under Changing Climate in the Upper Kafue River Basin, Southern Africa: A Large Scale Hydrological Model Application. Stochastic Environmental Research and Risk Assessment, 27, 1883-1898. https://doi.org/10.1007/s00477-013-0724-Z

[79] Ngongondo, C., Xu, C.-Y., Tallaksen, L.M. and Alemaw, B. (2013) Evaluation of the FAO Penman-Montheith, Priestly-Taylor and Hargreaves Models for Estimating Reference Evapotranspiration in Southern Malawi. Hydrology Research, 44, 706-722. https://doi.org/10.2166/nh.2012.224

[80] Alemaw, B.F. (2012) Hydrological Modeling of Large Drainage Basins Using a GISBased Hybrid Atmospheric and Terrestrial Water Balance (HATWAB) Model. Journal of Water Resource and Protection, 4, 516-522. https://doi.org/10.4236/jwarp.2012.47060

[81] Vision 2036 CA (Vision 2036 Coordinating Agency) (2020) Botswana Vision 2036, Achieving Prosperity for All. Pillars. https://vision2036.org.bw/ 